https://doi.org/10.51196/srz.18.4

\title{
BŁOGOSŁAWIONY AUGUSTYN ${ }^{1}$
}

\author{
Jewgienij Nikołajewicz Trubieckoj
}

\section{/// Światopogląd błogosławionego Augustyna - geneza}

Błogosławiony Augustyn to jedna z najbardziej interesujących osobowości w dziejach, a jej ocena stanowi jedno z najtrudniejszych zadań. Dzieje się tak z powodu różnorodności i bogactwa elementów składających się na nauczanie Augustyna i tak lub inaczej oddziałujących na kształtowanie się jego charakteru. Augustyn jest w każdym wymiarze ucieleśnieniem granicznego $\mathrm{V}$ stulecia, kiedy jeden zmurszały świat pogrążał się w ruinie, a drugi powstawał na jego zgliszczach. Stoi on na granicy między starożytnością a wiekami średnimi: gromadzi okruchy kultury starożytnej, a jednocześnie kładzie fundamenty pod średniowieczny, a po części i nowoczesny europejski pogląd na świat. Mówiąc słowami Charpentiera, Civitas Dei Augustyna jest „mowa pogrzebową nad starym światem i jednocześnie uroczystą proklamacją świata nowego"2. Te słowa mogą służyć za wspaniałą charakterystykę całego życia i działalności naszego ojca Kościoła. To

\footnotetext{
1 Tekst jest skróconą wersją dwóch pierwszych części rozprawy Jewgienija Nikołajewicza Trubieckiego Fitosofja christianskoj tieokratii w $V$ wiekie, która ukazała się w czasopiśmie „Woprosy fiłosofii i psichologii" w latach 1891 i 1892. Zachowane zostały oryginalne tytuły obu tłumaczonych części. Tytuł całości pochodzi od tłumacza.

${ }^{2}$ Chodzi tu o Jean-Pierre'a Charpentiera (1798-1877), filologa i historyka, znawcę literatury starożytnej i renesansowej. Cyt. za J.P. Charpentier, Études sur les pères de l'Église, Paris 1853, s. 280: „l'ouvrage d'Augustin est l'oraison funèbre du monde ancien en même temps qu'il est l'annonce éclatante du monde nouveau" (Trubieckoj mógł znać oryginał lub niemieckie tłumaczenie Studien über Kirchenvater, tłum. F. Bittner, Mainz 1855). Przypisy w tekście pochodzą zarówno od autora, jak i tłumacza. Te ostatnie zostały każdorazowo oznaczone na końcu lub - jeśli stanowia rozwinięcie przypisu autorskiego - mieszczą się w nawiasie kwadratowym. Jedynym wyjątkiem są te przypisy autorskie, w których Trubieckoj odwołuje się do prac posiadających polski przekład, wtedy podmieniam odniesienie bibliograficzne z oryginału na odsyłacz do analogicznego miejsca w tekście polskim, tego zabiegu nie zaznaczam osobno [przyp. tłum.].
} 
osobowość pod każdym względem dwoista: ucieleśnia ona i skupia w sobie wszystkie przeciwieństwa swojego wieku. Ponadto Augustyn przewidział i połączył w sobie opozycje nowych czasów, jako że będąc ojcem i - można powiedzieć - twórcą średniowiecznego katolicyzmu, równocześnie ze względu na inne aspekty swojej doktryny był prorokiem protestantyzmu. I jeśli protestanci i katolicy maja jednakowe prawo, by widzieć w nim swojego ojca założyciela, to my bez żadnych watpliwości możemy uznać go za ojca zachodniego chrześcijaństwa we wszystkich jego głównych odgałęzieniach.

Augustyn - syn rozwiązłego afrykańskiego poganina i chrześcijańskiej świętej - przez całe swoje życie pozostaje ambiwalentnym płodem pogaństwa i chrześcijaństwa, które walczą w nim do końca jego życia, nie będąc w stanie całkowicie przemóc jedno drugiego. Wewnętrzna walka tego człowieka to walka światowa, a proces rozwoju psychologicznego, który uwiecznił on w swoich Wyžnaniach, jest pięknym odzwierciedleniem światowego kryzysu. Dwóm przeciwstawnym usposobieniom łączącym się w życiu Augustyna, rozpasanemu pogaństwu jego młodości i świętemu chrześcijaństwu wieku dojrzałego, odpowiadają dwa środowiska społeczne; jego wewnętrzne rozdwojenie jest rozdwojeniem ówczesnego społeczeństwa.

Ojczyzna Błogosławionego Augustyna, północna Afryka, stanowi wyraźną ilustrację owego rozdwojenia społecznego. To tu przeciwstawne nastroje społeczne zyskuja na sile za sprawa gwałtownej i zachwycającej afrykańskiej przyrody. Afryka w interesującym nas okresie to kraj kontrastów: tu spotykamy skrajny ascetyzm sąsiadujacy z najbardziej wyuzdana rozpustą, płomienną religijność obok najprzeróżniejszych uczuciowych ekscesów. Współczesny Augustynowi, choć młodszy od niego, Salwian ${ }^{3}$ opisuje Afrykę jako jakiś powszechny dom rozpusty: cnotliwy Afrykańczyk to - wedle jego słów - już nie Afrykańczyk. To kraj najgorszych występków przeciw naturze. Trudno jest przejść ulicami afrykańskiej stolicy Kartaginy nie skalawszy się - mówi Salwian ${ }^{4}$. A równocześnie, jak wiemy, Afryka jest ojczyzną największych nauczycieli Kościoła, takich jak Tertu-

\footnotetext{
${ }^{3}$ Salwian z Marsylii (ok. 400-?) - pisarz wczesnochrześcijański, mnich i kapłan, w swoim głównym dziele De gubernatione Dei (O rz̨adach Boga) analizuje proces rozkładu państwa rzymskiego w kategoriach Boskiej kary za niemoralny styl życia i wezwania do odnowy obyczajów [przyp. tłum].

${ }^{4}$ Trubieckoj zdaje się w powyższej trawestacji odnosić do następującego fragmentu z dzieła Salwiana: „Czy była jakaś część Kartaginy, która nie byłaby przepełniona rozpustą? Czy było w tym mieście jakieś miejsce, gdzie nie byłoby domu publicznego? Śmiem powiedzieć, że niemal na wszystkich ulicach i wszystkich drogach czyhały pułapki rozpusty osaczające niczym sidła demoralizacji, a zatem ci, którzy odczuwaliby odrazę przed tego typu rozwiązłością, z ledwością
} 
lian, oraz takich świętych, jak męczennik Cyprian i sam Augustyn. Tenże Salwian przeraża się areligijnościa afrykańskiego społeczeństwa, nie wyłączając chrześcijan, którzy łączą oba kulty - składają ofiary bożkom, a potem przychodzą przed chrześcijańskie ołtarze. Cechę charakterystyczną Afrykańczyków stanowi ich nienawiść do mnichów i ascetów. Mnich, przybywający do Kartaginy, narażał się na przekleństwa, drwiny i zniewagi. Apostołowie byli bezpieczniejsi, wtedy gdy wchodzili do pogańskich miast - mówi Salwian - niż mnisi wchodzący do chrześcijańskiej Kartaginy $^{5}$. Jak widać $z$ tego opisu, społeczeństwo jest rozdwojone pomiędzy ascetyzmem poszczególnych pokutników, wypędzanych na pustynię z powodu powszechnej nienawiści, a wyuzdaną rozpustą mas. Surowy i nieco skłonny do wyolbrzymiania Gaston Boissier ${ }^{6}$ słusznie ostrzega przed nadmiernym zawierzeniem świadectwu Salwiana, lecz w tym przypadku nie mamy powodu, aby wattpić w prawdziwość jego słów, ponieważ takie samo wrażenie wynosimy również z lektury pism Augustyna, a w szczególności z lektury Wyznań. Widzimy w nich wściekłe, rozpustne społeczeństwo jako ciemne tło, na którym na zasadzie kontrastu zaznaczają się takie wyjątkowe osobowości jak święta Monika.

Spolaryzowane przeciwieństwa w usposobieniu Augustyna odpowiadają w ten sposób spolaryzowanym przeciwieństwom ówczesnego społeczeństwa. Jakie sa główne doświadczenia jego życia? Z jednej strony to tłum ludzi upadłych moralnie, z drugiej - nieliczni święci, wybrane jednostki. Z jednej strony to bezwartościowe kulty i dzikie orgie odradzającej się starej religii, z drugiej - chrześcijaństwo, które jako jedyne daje swoim wyznawcom siłę, aby utrzymywać się na wysokim poziomie moralnym. Dysharmonię w sobie samym, wewnętrzny rozkład swojego środowiska, Augustyn uznał za walkę dwóch przeciwstawnych zasad. W swojej rozpustnej młodości doświadczał siły złej zasady, grzechu, lecz nie był to tylko indywidualny, osobisty grzech: żył ,jak wszyscy”, powtarzając grzechy swojego społeczeństwa, gdzie cnotliwość uważało się za coś godnego wstydu. Był to grzech społeczny, a jednocześnie grzech gwałtownej i skłonnej do uniesień ojcowskiej natury, a co z tego wynika - grzech rodowy, odziedziczony. Środowisko społeczne i odziedziczona fizyczna struktura popycha mogliby tego uniknąć" - O rzadach Boga, ks. VII, rozdz. XVII, \72, [w:] Salwian z Marsylii, Dzieła wszystkie, Warszawa 2010, s. 238 [przyp. tłum.].

5 Tamże, ks. VIII [Trubieckoj uwypukla tu opozycję, którą Salwian przedstawia w $\int \mathbb{S} 22$ i 23 rozdziału IV, w polskim wydaniu: s. 254].

${ }^{6}$ G. Boissier, La fin du paganisme. Étude sur les dernières luttes religieuses en occident all quatrième siècle, t. II, Paris 1891, s. 485 [Gaston Boissier (1823-1908) - francuski filolog klasyczny i historyk, członek i sekretarz Akademii Francuskiej, zajmował się poezją łacińską oraz historycznym procesem akceptacji chrześcijaństwa w starożytnym Rzymie]. 
go na drogę rozpusty, zła. Z drugiej strony, tym złym i nieokiełznanym dążeniom sprzeciwiają się resztki chrześcijańskiego usposobienia, ocalałe pod postacią niejasnych dziecięcych wspomnień. Owe przeżycia młodości zawieraja już w sobie zasadniczy kontrast, który później określił cały światopogląd Augustyna: z jednej strony, grzech staje się czymś nie tylko indywidualnym, lecz także społecznym i dziedzicznym - vitiata natura; z drugiej strony mamy siłę dobra i łaski; zarówno tłum błądzących i ginących, massa perditionis, jak i ograniczona liczbę wybranych. W cytowanym już dziele De gubernatione Dei Salwian mówi: „Natomiast nie znam grzechu, który nie panowałby niemal u wszystkich Afrykańczyków", a w innym miejscu: „gdybyś nawet bardzo pilnie szukał, jednego zaledwie czystego możesz znaleźć w Kościele" ". Porównując choćby te dwie sentencje i wszystko to, co Salwian mówi o Afrykańczykach, bez trudu zrozumiemy, dlaczego dla Afrykańczyka takiego jak Augustyn siła zła musiała jawić się jako coś bezmiernego, nieprzezwyciężalnego przy pomocy przyrodzonych sił człowieka, a dobro, przeciwnie - musiało wydawać się czymś absolutnie ponadnaturalnym, ponadludzkim. Wyjaśnia nam to całkiem dużo w filozofii Augustyna, a między innymi to, dlaczego w jego etycznym poglądzie na świat wartość pierwiastka ludzkiego jest zaniżona, a on sam - skazany na czysto pasywną rolę, dlaczego w jego systemie nie ma miejsca dla ludzkiej wolności. System ten rozdarty jest między przeważającą w rozpustnej ludzkiej naturze siłą zła a niepowstrzymaną siłą łaski, która jako jedyna jest w stanie pokonać zło. Pomiędzy tymi dwoma biegunami człowiek jest niczym. Jego wolność w całości pochłaniana jest to z góry, to z dołu, wszystko zmienia się w grzech lub w łaskę.

W wieku powszechnej dezintegracji i rozkładu jednostka czuje się samotna i chcąc nie chcąc skupia się na swoim świecie wewnętrznym. Dlatego też nie zdziwi nas, że filozofowanie Augustyna rozpoczyna się od zgłębienia samego siebie i samobadania. W najnowszej literaturze niejednokrotnie wskazuje się na jego subiektywizm, skłonność do refleksji, przechodząca w bolesne wsłuchiwanie się w siebie. Szczególnie często lubią podkreślać w nim tę pokrewną cechę niemieccy historycy protestanccy ${ }^{8}$. Mówią oni, że

\footnotetext{
Salwian z Marsylii, O rzqdach Boga, ks. VII, rozdz. XV, \64, dz. cyt., s. 236 [Tekst rosyjski jest bardziej literalnym tłumaczeniem frazy łacińskiej: „In Afris paene omnibus nescio quid non malum”] oraz tamże, ks. VII, rozdz. XVII, \ 75, s. 239 [fraza łacińska: „castum vel in ecclesia inuenire vix posses"].

${ }^{8}$ [Zob.] H. Siebeck, „Zeitschrift für Philosophie und philosophische Kritik”, 1888, od s. 170 [chodzi tu o: Die Anfänge der neueren Psychologie in der Scholastik. 1: Der ältere Augustinismus, „Zeitschrift für Philosophie und philosophische Kritik", nr 93/1888, s. 161-216]; A. Harnack, Dogmengeschichte, t. III, s. 97 [Trubieckoj mógł korzystać jedynie z pierwszego, trzytomowego wydania Lebrbuch der Dogmengeschite (Freiburg im Breisgau 1886 - t. I, 1888 - t. II, 1890 - t. III). W niniejszym fragmencie
} 
centralnym w spekulacji Augustyna jawi się subiektywny wewnętrzny świat ludzkiej świadomości, woli i uczucia. „Wszystko, co zewnętrzne, ma dla niego znaczenie i wartość tylko wtedy - mówi Siebeck ${ }^{9}$ - kiedy pojawia się w refleksji nad tym, co wewnętrzne" ${ }^{\text {", }}$, wszystko, co obiektywne interesuje go tylko w warstwie jego stosunku do człowieka i jego świata wewnętrznego. Na pierwszym miejscu stawia on - wedle Siebecka - coś najbardziej intymnego, życie duszy ludzkiej w Bogu. Rzeczywiście sam Augustyn pisze w swoich Solilokwiach, że chce znać tylko duszę i Boga, i nic więcej ${ }^{11}$. Bylibyśmy jednak skrajnie niesprawiedliwi wobec naszego ojca Kościoła, jeśli widzielibyśmy w jego myśleniu jedynie subiektywizm i gdybyśmy sprowadzali jego filozofię do subiektywnej tylko refleksji. Subiektywizm tego czasu, jak już było powiedziane, odpowiada poczuciu samotności skoncentrowanej na sobie jednostki i jeśliby myślenie naszego ojca Kościoła wyczerpywało się w samej tylko refleksji, to nigdy nie wydobyłby się on ze stanu egoistycznego odosobnienia, umysłowego i moralnego, i nie mógłby nigdy wznieść się ponad indywidualizm swojego społeczeństwa. W każdym razie nie ta jego cecha czyni go twórca średniowiecznej teokracji i autorem Civitas Dei. W rzeczy samej jest on człowiekiem kontrastów i łączy w swej świadomości najbardziej różnorodne elementy. Uświadomiwszy sobie marność materialnego, zmysłowego świata, pogrąża się w samym sobie, ale tylko po to, aby, uznawszy próżność i marność zamkniętej w sobie istoty ludzkiej, wyjść z tego stanu ku mistycznej kontemplacji. „Nie wychodź na świat (noli foras ire) - mówi w jednym ze swoich najwcześniejszych pism napisanym tuż po przejściu na chrześcijaństwo - wróć do siebie samego: we wnętrzu człowieka mieszka prawda. A jeśli dostrzeżesz zmienność własnej istoty, wykrocz nawet poza siebie samego (transcende te ipsum). Pamiętaj jednak, że skoro wykraczasz poza siebie samego, wykraczasz poza duszę rozumną. Dąż więc tam, skąd samo światło rozumu bierze swą jasność"12. Zgłębianie

odnosi się on do stwierdzeń Harnacka zamieszczonych w przypisie 4 rozpoczynającym się na stronie 95 , a rozciagającym się na strony 96 i 97$]$.

${ }^{9}$ Hermann Siebeck (1842-1920) - niemiecki historyk filozofii i psychologii, zajmowal się historia filozofii greckiej, myśla Arystotelesa, był autorem encyklopedycznej pracy poświęconej historii psychologii od początków aż po Tomasza z Akwinu (Geschichte der Psychologie, t. I i II, Gotha 1880) [przyp. tłum.].

${ }^{10}$ H. Siebeck, Die Anfänge..., dz. cyt., s. 188.

${ }^{11}$ Deum et animam scire cupio. Nibilne plus? Nibil omnino. [Te trzy zdania to urywek z dialogu Augustyna z Rozumem znajdujący się we fragmencie II, 7 Solilokwiów; w tłumaczeniu polskim brzmi: „A. Chcę poznać Boga i duszę. R. Czy nic więcej? A. Nic zgoła" - Augustyn, Solilokwia, tłum. A. Świderkówna, [w:] tegoż, Dialogi filozoficzne, Kraków 1999, s. 244].

${ }_{12}$ Augustyn z Hippony, O prawdżinej wierže, XXXIX, 72, tłum. J. Ptaszyński, [w:] tegoż, Dialogi..., dz. cyt., s. 788. Por. analogiczne miejsca w Tractatus XX in Evangelium Ioannis, \ 11: „Transcende corpus et sape animum. Transcende et animum et sape Deum. Tu si in animo es in medio es. Si infra attendis, corpus est; si supra attendis, Deus est” [,Wykrocz także poza ciało i myśl o duszy, 
samego siebie, samoanaliza, jak widać z tego cytatu, to tylko punkt wyjścia w filozofii Augustyna, a ostatecznym jej celem jest poznanie ponadnaturalnej rzeczywistości, owego świata w niebiosach, to zaś leży poza granicami tego, co subiektywne, i tego, co ludzkie.

Silnie rozwinięte samoczucie to bezwarunkowo własność wyróżniajaca naszego myśliciela, a subiektywizm to z pewnością cecha jego charakteru. Nie należy jednak zapominać, że wyłączne panowanie samoczucia, poszukiwanie przez indywiduum utwierdzenia wyłącznie w samym sobie to $-z$ punktu widzenia filozofii Augustyna - najwyższe zło, pryncypium wszystkiego, co złe. Przez całe życie zmagał się on ze swoim subiektywizmem, choć nigdy nie był w stanie całkowicie go przezwyciężyć. Zgłębianie samego siebie, samoanaliza to dla niego początek rezygnacji z siebie: zagłębiając się w siebie, znajduje jedynie rozkład wewnętrzny - to samo zmaganie światowych przeciwieństw - dobra i grzesznej natury, od której szuka ocalenia. Droga jego filozofowania wiedzie od rozkładu i rozdwojenia życia osobistego do obiektywnego świata i jedności. Jak długo zamykamy się w naszym świecie uczuciowym, znajdujemy w sobie tylko sam mrok i cierpienia. „Czyż nie widzisz i nie przerażasz się z powodu tej otchłani? - zakrzyknie Augustyn. I czymże jest ona, jeśli nie naszą naturą, a przy tym nie taką, jaka była wcześniej, ale taka, jaką jest teraz. I tak, bardziej staramy się ja poznać, niż rzeczywiście pojmujemy"13. Całe myślenie Augustyna w jego okresie przedchrześcijańskim to szereg kolejnych gigantycznych starań, aby wyrwać się z tej negatywnej i mrocznej głębi subiektywnej świadomości ku światu obiektywnemu i prawdzie, aby oswobodzić się od swej indywidualnej grzeszności i fatalnego rozdwojenia osobowości. On sam tak mówi w Wyznaniach o tym okresie swojego życia, kiedy, uwolniwszy się już od manicheizmu, nie zwrócił się jeszcze ku chrześcijaństwu: „Usiłowałem podźwignąć moją zdolność rozumienia z przepaści, w jakiej była pogrążona. Ale znowu spadałem w tę otchłań. Znowu się dźwigałem w górę i znowu, znowu spadałem w dół"14. Jedynym, co podnosiło go ku obiektywnemu Bożemu światłu - opowiada - był fakt, że wola wydawała mu się nie bardziej wiarygodna, niż jego istnienie, quod tam me sciebam habere voluntatem, quam me vivere. A argumenty sceptyków nigdy nie mogły zachwiać tą wewnętrzną pewnością samoświadomości. Lecz w swojej woli Augustyn znajdował jedynie wewnętrzną sprzeczność, tylko nieodwracalny rozkład.

wykrocz też poza duszę i myśl o Bogu. [...] Jeśli zaś jesteś w duszy, jesteś w środku: jeśli zwrócisz wzrok niżej, jest ciało; jeśli zwrócisz wzrok wyżej, jest Bóg” - tłum. M.R.].

${ }_{13}$ Augustyn z Hippony, De anima et eius originum, IV, 7.

${ }^{14}$ Tegoż, Wyznania, VII, 3, \5, tłum. Z. Kubiak, Kraków 1994, s. 139. 
Jako że to wola jest przyczyną mojego grzechu, lecz ja sam grzechu nie chcę i czynię to, czego nienawidzę. „Czyniąc grzech bezwolnie, raczej go doznaję, niż czynię" ${ }^{\prime 15}, \mathrm{i}$ - konsekwentnie - stan niewoli jest raczej karą, niż winą, a przy tym karą, której doznaję sprawiedliwie ${ }^{16}$. Dalej jest coś całkowicie godnego zaufania, co góruje nad moimi sprzecznościami, w samym rozkładzie dostrzegam obiektywne prawo absolutnej sprawiedliwości - taki jest tok myślenia Augustyna. Całkowita wiarygodność mojej woli, mojego istnienia sprowadza się do absolutnej wiarygodności tego obiektywnego dobra, owego obiektywnego pokoju i porządku, którego potrzeba mojej woli. Rozdwojenie i rozkład są formami czasowej rzeczywistości, a pokój i jedność to jej wieczny ideał.

Kluczowy motyw filozofii Augustyna to poszukiwanie takiego kosmosu, który przezwyciężałby kontrasty czasowej rzeczywistości, jej niedobra dwoistość przemieniał w jedność powszechnego pokoju. Poszukiwanie to przede wszystkim bolesny i męczący proces, w nim duchowe męki rodzenia nowego świata łączą się z przedśmiertnymi cierpieniami starego. Aby stać się ojcem założycielem średniowiecznego poglądu na świat, Augustyn musiał samemu doświadczyć pogaństwa i je pokonać. Złączył on w sobie i wycierpiał wszystkie choroby swojego wieku, w pełnym sensie tego słowa sam niósł krzyż swojego społeczeństwa. Będąc już na drodze ku nawróceniu, będąc już w połowie chrześcijaninem, Augustyn opowiada: „Lecz jednocześnie w wielkiej gorączce badałem, skąd zło pochodzi. Jakież bóle rodzenia przeżywało serce moje! Jakież z niego dobywały się jęki! O, Boże mój!”. Oto niepokój duszy (tumultus animae), niewyrażalny i nieprzekładalny na słowa, którego - kontynuuje Augustyn - nikt z ludzi nie mógł ze mną dzielić ani zrozumieć, którego słuchał jedynie niewidzialny Bóg: Tu sciebas, quid patiebar, nullus hominum. Niecałkowicie jeszcze odcinając się od manicheizmu, czytamy dalej w Wyznaniach, szukał prawdy na zewnątrz, w odczuwanym zmysłami wszechświecie, wtedy gdy światło prawdy jest wewnątrz nas. „Nie było go w przestrzeni, a ja wpatrywałem się w przedmioty istniejące $\mathrm{w}$ przestrzeni. I nigdzie wśród nich nie znajdowałem

\footnotetext{
${ }_{15}$ Podaję tu mój przekład rosyjskiej wersji cytatu zamieszczonej przez Trubieckiego, który odbiega od oryginalnego tekstu Wyznań o postaci: „Quod autem invitus facerem, pati me potius quam facere videbam” (Confessiones, lib. VII, cap. 3, \$ 5). Wierny oryginałowi jest polski przekład: „Ilekroć bowiem czyniłem coś mimowolnie, odczuwałem, że raczej doznaję, niż czynię" - Augustyn z Hippony, Wyznania, dz. cyt., s. 140 [przyp. tłum.].

${ }_{16}$ Augustyn z Hippony, Wyznania, VII, 3, \5 , dz. cyt., s. 139. Sprawiedliwie doznaję kary, bowiem zło mimo wszystko jest stanem mojego chcenia, mojej woli, choć podzielonej wewnętrznie i dlatego też wewnętrznie sprzecznej. W takim znaczeniu słowa grzech jest z jednej strony aktem mojej woli, ale jednocześnie też aktem bezwolnym, ponieważ moja wola nie ma władzy nad sobą samą i jest wewnętrznie sprzeczna.
} 
oparcia i ukojenia. Ani nie przygarniały mnie one tak, abym mógł rzec, że jestem nasycony, że jest mi dobrze". Dla rozdwojonej świadomości cały świat wydaje się czymś absolutnie zewnętrznym, obcym i wrogim. Szukając czegoś większego od siebie, absolutnego dobra i prawdy, i pytając o świat zewnętrzny, Augustyn widzi w nim tylko to, co najniższe, i nie znajduje pokoju. Ten obcy i wrogi świat nie wybawia go od wewnętrznego niepokoju, lecz dławi i przygniata jego świadomość. „Lecz gdy w pysze powstałem przeciw Tobie, gdy wyruszyłem do walki przeciw Panu, chlubiąc się siłą tarczy mojej - kontynuuje Augustyn - nawet te najniższe rzeczy wyrosły nade mnie, osaczały mnie i dusiły. Na próżno szukałem, skąd bym mógł tchu zaczerpnaćć. Świat odczuwany zmysłami dławił go od zewnątrz swą obca gromada, a kiedy zagłębiał się on w swej świadomości, to i tu obrazy rzeczy materialnych nie odstępowały go i prześladowały, a wszystko razem zdawało się mówić: „Dokąd, tak niegodny i zbrukany, idziesz?”17.

Nikt głębiej i wierniej niż Augustyn nie przedstawił owej wewnętrznej sprzeczności, głębokiego rozdwojenia, przenikającego w najtajniejsze głębiny naszej moralności. Brak jedności i harmonii oto fundamentalna właściwość naszej zepsutej natury. Nasza wola nakazuje jedno, a czyni drugie. Tym samym nie $z$ całej swej istoty chce, nie z całej istoty zamierza (non ex toto vult, non ex toto imperat). „W takim tylko stopniu nakazuje, w jakim chce; a w takim stopniu udaremnione jest to, co nakazuje, w jakim nie chce tego. Oto wola nakazuje, żeby była wola - nie jakaś inna, lecz ona sama" (to znaczy: wola jako imperatyw nakazuje ten lub inny postępek, który sam jest jednocześnie aktem woli). „Ale nie w pełni nakazuje; więc nie wypełnia się to, co ona sama nakazuje" (to znaczy: nie ma jednego integralnego podmiotu działania, non est quod imperat). „Gdyby była pełna (si plena esset), to by sobie nie nakazywała być, bo już by była przecież", to znaczy: jeśli wola nie byłaby wewnętrznie podzielona, to nie byłoby rozdwojenia między zamierzeniem a działaniem i zamiar pokrywałby się w niezapośredniczonej jednoczesności z wykonaniem. Ten nienormalny stan ducha, w którym wola po części chce, a po części nie chce, jednostka zaś targana jest sprzecznymi życzeniami i odczuciami, Augustyn nazywa potwornościa (monstrum), chorobą ducha (aegritudo animi). W istocie ,wola rozszczepia się na dwie wole, z których żadna nie jest wola całkowita; jedna ma to, czego drugiej brakuje" ${ }^{\prime 18}$. Wszystko w naszym świecie wewnętrznym jest podzielone, wszystko w nim jest zmaganiem, chaosem i sprzecznością.

${ }^{17}$ Powyższe cytaty za: Augustyn z Hippony, Wyznania, VII, 7, dz. cyt., s. 147.

${ }_{18}$ Powyższe cytaty za: tamże, VIII, 9, $\$ 21$, s. 177. 
Czytając Augustyńskie Wyznania, czujemy, jak rozwiera się przed nami bezdenna otchłań subiektywnej świadomości, lecz w tej subiektywnej głębi walczą ze sobą obiektywnie istniejące w świecie kontrasty. Dostrzegamy w niej psychologiczny proces, którego w mniejszym lub większym stopniu doświadczają wszyscy, zdobywający wiarę za cenę walki i wysiłków, dochodzący do niej na drodze długich poszukiwań i wątpliwości. Równocześnie można traktować Wyznania jak subiektywny opis ówczesnego społeczeństwa, rozdartego między dwoma przeciwstawnymi biegunami rozpasanej natury zmysłowej i ascetycznej świętości.

\section{$* * *$}

Dostrzegając rozdwojenie u samej podstawy naszego jestestwa, Augustyn widzi w nim początek rozkładu i śmierci. Nasze ziemskie życie jest procesem nieustannego umierania. Wrogość duszy i ciała, wrodzony dualizm naszej natury to sposób przejawiania się w nas śmierci, a ostateczne oddzielenie się duszy od ciała, śmierć ciała - to tylko ostatnie ziemskie stadium tego bolesnego procesu. Pierwszym w porządku czasu przejawem śmierci jest sama nasza natura vitiata: doświadczamy jej poprzez sprzeciw naszego ciała, które nie stosuje się do żądań naszej świadomości, i poprzez wewnętrzne rozbicie tejże świadomości i woli. Śmierć rozpoczęła się już wtedy, kiedy pierwszy człowiek odczuł w swoich członkach „wrogie nieposłuszeństwo zmysłowych pragnień" (repugnantem inoboedientiam concupiscendi), tym samym został poddany nieuchronności śmierci (necessitas moriendi). Człowiek nie włada już w ogóle swoim ciałem, a jego utrata, śmierć fizyczna jest jedynie konsekwencją ogólnego nienaturalnego stanu, naszej niezdolności do podporządkowania sobie i ujarzmienia naszego ciała ${ }^{19}$. Śmierć ma swoje źródło w samej naturze istnienia w czasie, w którym wszystko nieprzerwanie przemija, a nasze ziemskie życie jest nieustannym cursus ad mortem. „Nigdy więc człowiek nie trwa w życiu, odkąd przebywa w tym umierającym raczej

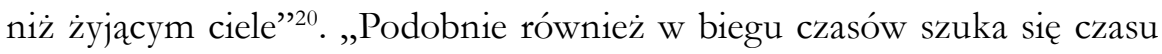
teraźniejszego i nie znajduje go się, gdyż to, przez co się przechodzi z przyszłości w przeszłość" (to znaczy: nieskończenie krótki moment w czasie), „nie odznacza się żadnym zgoła trwaniem (sine ullo spatio est)"21. Ułomna dwoistość posiada swoje źródło w samej formie czasu: wszystko rozdwaja

\footnotetext{
19 Zob. tegoż, O państwie Bożym, ks. XIII, rozdz. 2, 3, tłum. W. Kornatowski, Warszawa 1977, t. II, s. $86-89$.

${ }^{20}$ Tamże, ks. XIII, rozdz. 10, t. II, s. 95.

${ }^{21}$ Tamże, ks. XIII, rozdz. 11, t. II, s. 96.
} 
się na nieskończone przeszłe, którego nie jesteśmy w stanie zatrzymać, i na niekończące się przyszłe, które - kiedy tylko go dosięgniemy - uchodzi w przeszłość, nie dopełniając wewnętrznie naszego życia. W tym niespokojnym ruchu poszukujemy czegoś obecnego i nie znajdujemy tego ${ }^{22}$. Nie możemy nigdzie znaleźć spokoju, ponieważ nie ma niczego teraz obecnego. Nieustannie umieramy i nieustannie wewnątrz pełni jesteśmy trwogi.

Rozdwojenie i śmierć to powszechne prawo całej rzeczywistości, dotyczące wszystkiego, co istnieje w czasie. Uwaga Augustyna w całej jego filozofii skupia się na zasadniczym pytaniu: jak uchronić się od śmierci, jak przezwyciężyć ułomną dwoistość ludzkiej natury? Przed oczami Augustyna staje ideał pełnej istoty ludzkiej, znajdującej się w stanie pokoju i spokoju. Z kolei, fundamentalne pytanie jego filozofii można sformułować również w taki sposób: jak może się zbawić istota ludzka? Ale przecież zło jest ze swej natury powszechne i obiektywne: leży tak u podstaw społeczeństw ludzkich, jak i u podstaw konstrukcji przyrody w ogóle, do której jako istoty fizyczne przynależymy. Stąd też wypływa kolejne pytanie: jak może się zbawić wspólnota ludzka, jak może dostapić zbawienia wszechświat? Idealna, pełna istota ludzka da się pomyśleć tylko w społeczeństwie idealnym, w idealnym uwolnionym od czasu wszechświecie, w którym wszystko jest jedne i pełne, wszystko trwa w stanie pokoju wewnętrznego, spokoju i równowagi. W naszym doświadczeniu nie natrafiamy jednak na taki wszechświat, jest to ideał absolutnie transcendentny w stosunku do naszej ziemskiej rzeczywistości, gdzie wszystko pozostaje ze sobą w stanie wrogości. Taki wszechświat jest przedmiotem nadziei. Jeśli ułomna dwoistość naszej natury, śmierć i zło są negatywnym założeniem filozofii Augustyna, to wszechświat, rozumiany jako pełnia powszechnego pokoju, jest pożądanym ideałem. Augustyn nie chce jedynie dobra wewnętrznego jednostki, w pełni uświadamia sobie, że człowiek nie może zbawić się jedynie o własnych siłach, dlatego też pytanie o zbawienie jednostki jest dla niego przede wszystkim pytaniem o obiektywną zasadę zbawienia. Podobnie jak grzech nie stanowi jedynie indywidualnej, jednostkowej własności, ale coś powszechnego i dziedzicznego, tak samo i działanie owej obiektywnej zasady zbawienia powinno ucieleśniać się w kosmicznej strukturze społecznej, w ludzkości, ze względu na jedność wypływająca ze wspólnoty pochodzenia. W ten sposób pytanie o zbawienie jednostki staje się dla niego jednocześnie problemem społecznym i kosmicznym.

Znając główny wątek filozoficznych poszukiwań Augustyna, łatwo zrozumiemy ów proces rozwoju wewnętrznego, który poprzez szereg ko-

${ }^{22}$ Zob. tegoż, Wyznania, ks. XI, rozdz. 11, 15, dz. cyt., s. 264 i 266-269. 
lejnych stopni przywiódł go ku chrześcijaństwu, i będziemy w stanie pojąć sukcesywnie zachodząca genezę jego światopoglądu. Nie mam powodu, aby dokonywać tu szczegółowego streszczenia biografii Augustyna ${ }^{23}$. Główne etapy życia tego wielkiego nauczyciela Kościoła są aż nazbyt dobrze znane $\mathrm{i}$ interesują nas tutaj tylko dlatego, że pozwalają łatwiej zrozumieć proces powstania i rozwoju jego systemu.

Każdy z nas już w szkolnych ławach słyszał o burzliwej młodości Augustyna, kiedy utraciwszy naiwną dziecięcą wiarę, pozbawiony chrześcijańskich fundamentów płacił haracz swoim czasom i swemu społeczeństwu, żyjąc życiem mikroskopijnych interesów własnego egoizmu, rozdarty między zadufaniem a zmysłowościa. Jednak już w tym czasie świat zewnętrzny ze swoimi rozkoszami nie był w stanie zadowolić i nasycić przyszłego myśliciela. Filozoficzne powołanie ujawnia się w nim już na tym etapie jak smutny ferment, mimowolna tęsknota za ideałem, jako niezadowolenie z rzeczywistości, brak satysfakcji z tego, co teraz obecne.

Pod wpływem Hortensjusza Cycerona, z którym zapoznaje się w wieku lat 19, smutne poszukiwanie przeobraża się w świadomą refleksję filozoficzna. Niezachowane do naszych czasów dzieło Cycerona stanowiło wymowną zachętę do filozofowania. Wedle świadectwa samego Augustyna rozbudziło ono w nim świadomą miłość do mądrości, świadomą potrzebę jej poszukiwania. „Przed mymi oczyma zmarniały nagle wszystkie ambicje światowe - mówi Augustyn. Niewiarygodnym wprost żarem serca zacząłem tęsknić do nieśmiertelności, jaką daje mądrość”24. W ten sposób już na najwcześniejszym etapie swojego rozwoju myślenie filozoficzne Augustyna posiada silnie idealistyczny charakter. Jednak ten idealizm młodości nie znalazł wyrazu w żadnym określonym światopoglądzie filozoficznym, był raczej rodzajem impulsu. Refleksja filozoficzna unicestwiła dla niego świat złudnych pragnień i próżnych marzeń, którymi żył do tej pory, obróciła wniwecz jego samozadowolenie. Idealizm filozoficzny, wyrażający się poprzez świadomość niewspółmierności rzeczywistości względem poszukiwanego ideału, stał się dla niego tylko nowym źródłem cierpienia i bólu. Nie uzdrowił go, wręcz przeciwnie - pogłębił jego nieznośny stan moralnego rozdwojenia i rozpadu.

\footnotetext{
${ }^{23}$ Aby zapoznać się bliżej z biografią Augustyna, odsyłam do następujących solidnych prac: C. Bindemann, Der beilige Augustinus, Berlin 1844 (w 3 tomach) oraz jedenasty tom pracy Böhringera Kirchengeschichte in Biograpbien (Aurelius Augustinus), Stuttgart 1877. Napisana bez talentu nudna książka Poujoult, Histoire de St. Augustin (w 2 tomach), również zawiera wiele danych faktograficznych o interesującym nas autorze. [Współczesne godne uwagi i dostępne w języku polskim pozycje zawierające szczegółową biografię Augustyna to choćby: A. Kijewska, Święty Augustyn, Warszawa 2007 czy P. Brown, Augustyn z. Hippony, tłum. W. Radwański, Warszawa 1993].

${ }^{24}$ Augustyn z Hippony, Wyznania, ks. III, rozdz. 4, dz. cyt., s. 59.
} 
To w tym momencie rodzi się to pesymistyczne usposobienie, które niedługo znajdzie dla siebie wyraz w manicheizmie Augustyna. Odwracając się od mrocznej głębiny subiektywnej świadomości ku kontemplacji obiektywnego wszechświata, nie jest on jednak w stanie wznieść się ku beznamiętnemu stosunkowi do niego, lecz przenosi na obiektywny kosmos swoje sprzeczności wewnętrzne. Walka wewnętrzna, której doświadcza w sobie samym, znajduje swoją hipostazę w walce dwóch obiektywnych zasad w świecie, w przeciwieństwie dwóch wrogich substancji - dobrej i złej. Przyglądając się uważnie manicheizmowi, przekonamy się, że ten system religijno-filozoficzny - w szczególności w swej zachodniej odmianie, której wyznawcą stał się Augustyn - nie jest niczym innym jak tylko swoistym dla tego czasu pesymizmem. Manicheizm to przede wszystkim: „konsekwentny, wyraźny dualizm o formie fantastycznej spekulacji na temat przyrody"25. Cały świat, wedle nauki manichejczyków, to rezultat przypadkowego zjednoczenia dobrej i złej zasady, światła i ciemności, które rozumie się materialistycznie, jako dwie materialne substancje, jako fizyczne światło i ciemność. Przedostawszy się do królestwa światła, książę mroku, szatan, uwięził część świetlistej substancji. Powstanie wszystkiego, co istnieje: nieba z jego gwiazdami, ziemi i wszystkiego, co na niej żyje, zostało uwarunkowane przez zniewolenie cząstek dobrej, świetlistej substancji, które starają się uwolnić z okowów złej zasady, szatana, który je więzi, i na powrót połączyć z królestwem światła, skąd przemoca zostały wyrwane. Takie wyzwolenie stanowi konieczny cel twórczego procesu, konieczny cel wszechświata. W ten sposób w systemie manichejskim zło staje się w istocie siła aktywną, a dobro jedynie pasywna - jego rola sprowadza się do czysto pasywnego samozachowania, samoobrony przed nacierająca siłą zła. Dobro może i ostatecznie powinno całkowicie oswobodzić się od zła, światło powinno oddzielić się od mroku, lecz samo zło jest niezniszczalne, jest współwieczne dobru i świetliste królestwo nie ma możności jego cał-

25 A. Harnack, Dogmengeschichte, t. I, dz. cyt., s. 685 [Nieco większy fragment w oryginale: „Das manichäische Religionssystem ist consequenter, schroffer Dualismus in der Form einer phantastischen Naturspeculation"]. Zob. całość tego wspaniałego szkicu na temat systemu manichejczyków - s. 681-694. Jak wiadomo, zachodni manicheizm końca IV i początku V wieku różni się od początkowego kształtu doktryny samego Maniego. Nie tworzymy tu jednak monografii manicheizmu i interesuje on nas o tyle, o ile oddziałał na Augustyna, i dlatego też możemy się tu ograniczyć do najkrótszych wzmianek o analizowanej doktrynie, opierając się przede wszystkim na informacjach, które można znaleźć w pracach samego św. Augustyna. Podobne informacje czytelnik znajdzie w szczegółowych pracach badawczych. Zob. G. Flügel, Mani, seine Lehre und seine Schriften, Leipzig 1862 (arabski tekst Muhammada bin Izaaka o Manesie, przekład i komentarz do przekładu); K. Kessler, Mani. Forschungen über die manichä̈sche Religion, Berlin 1889; F.C. Baur, Das manichäische Religionssystem, Tübingen 1831 (praca znakomita, lecz nieco przestarzała, tym bardziej, że autorowi nieznane były jeszcze arabskie źródła). 
kowitego przezwyciężenia i przeobrażenia w siebie. Usposobienie etyczne, odpowiadające dualistycznemu charakterowi systemu, to pesymizm - konsekwentny rezultat nauki, która z rozdwojenia, zaciekłej i wiecznej walki czyni fundament wszystkiego, co istnieje. Świat, jako dwoisty płód dobra i zła, stanowi coś sprzecznego, kłamliwego, przeznaczonego na zatracenie. Praktyczne zadanie człowieka we wszechświecie sprowadza się do zniszczenia tego nienaturalnego zjednoczenia poprzez poświęcenie się ascezie. W człowieku walka światowych zasad dochodzi do szczytu - człowiek to istota dwoista: stworzony przez szatana na jego obraz i podobieństwo, zawiera w sobie jednak cząstki światła w dużo większym stopniu, niż inne stworzenia. Szatan skupił w człowieku zniewolone cząstki dobra, aby poprzez niego panować nad nimi ${ }^{26}$; w człowieku więc oba wrogie sobie elementy osiagaja swoje najwyższe na ziemi skupienie. Oddając się cielesnym namiętnościom i egoistycznym aktom utwierdzania samego siebie, człowiek wspiera i podtrzymuje zniewolenie świetlistych cząstek, poprzez odżywianie się i rozmnażanie służy celom złej zasady, przykuwając dobro nowymi więzami do królestwa ciemności i przekazując ich zjednoczenie z pokolenia w pokolenie. Przeciwnie zaś - poprzez ascetyczne umartwienie i wyrzeczenie się samego siebie, poprzez post i wstrzemięźliwość - człowiek może i powinien sprzyjać wyswobodzeniu się zniewolonych cząstek światła ${ }^{27}$. Jednak takie wyższe zadanie praktyczne może zrealizować jedynie wtedy, gdy jest oświecony przez poznanie. Rola poznania, gnozy sprowadza się do tego, żeby objaśnić ludzkości istotną nienormalność istnienia,

${ }^{26}$ A. Harnack, Dogmengeschichte, t. I, dz. cyt., s. 743; C. Bindemann, Der heilige Augustinus, t. I, dz. cyt., s. 60 .

${ }^{27} \mathrm{O}$ ascetyzmie manichejczyków zob. interesujący rozdział 15 pracy Augustyna De moribus manicheorum [Trubieckoj mówi o drugiej księdze dzieła De moribus ecclesiae catholicae et de moribus manichaeorum libri duo]. Zniewolone cząstki Bóstwa nieprzerwanie uwalniaja się ex omni parte mundi i powracają do swojego królestwa. Lecz ulatniając się z ziemi, przedostają się do roślin, przyczepiając się za sprawą ich korzeni do ziemi i tym sposobem zapewniają siłę i energię życiową całemu światowi roślinnemu. Zwierzęta zaś w świecie roślin zdobywają pożywienie. Spółkując znów związują boskie cząstki z ciałem i sprowadzają je z ich prawdziwej drogi, wciągając na powrót w błędy i nieszczęścia: „I tym sposobem kiedy pokarm, który pochodzi z płodów ziemi i drzew, trafia do świętych, to znaczy - do manichejczyków, to zawarte w nim piękne pierwiastki bóstwa zostają oczyszczone dzięki ich czystości, modlitwom, śpiewaniu psalmów i udoskonalają się na wszelkie możliwe sposoby, aby powrócić do swego królestwa, uwolniwszy się od wszelkiego ciężaru i wszelkiej nieczystości" [W oryginale: Itaque cibi qui de frugibus et pomis parantur, si ad sanctos veniant, id est ad Manichaeos per eorum castitatem et orationes et psalmos, quidquid in eis est luculentum et divinum purgatur, id est omni ex parte perficitur, ut ad regna propria sine ulla sordium difficultate referatur]. W tym rozdziale ujawniony zostaje nieludzki charakter manichejskiego ascetyzmu. Jego podstawową motywacją nie jest - jak w chrześcijaństwie - zbawienie człowieka, lecz wręcz przeciwnie - triumf Boga na skutek zniszczenia człowieka. Ascetyzmowi temu obca jest miłość i Augustyn między innymi zarzuca manichejczykom to, że odmawiają bliźniemu - jeśli nie jest on manichejczykiem - pożywienia, a nawet wody z obawy, aby nie powstrzymał on drogi cząstek Bóstwa ku niebu. $\mathrm{O}$ ascetyzmie manichejczyków por. także: Augustyn z Hippony, Ennarationes in Psalmos, CXL, $\int 12$. 
zasadniczą sprzeczność wszechświata, a tym samym przygotować do aktu wyrzeczenia się samego siebie, samounicestwienia wszechświata poprzez poświęcenie się człowieka ascezie.

Pojawia się tu pytanie: co przywiodło Augustyna ku manicheizmowi? Po pierwsze, racjonalistyczny charakter systemu, który nie opiera się na jakimś zewnętrznym autorytecie, ale zwraca się ku ludzkiemu rozumowi, próbując dać racjonalne wyjaśnienie tego, co istnieje. Ten racjonalizm przypadł do serca myślicielowi, którego - wedle jego własnego świadectwa w tym czasie i odpychała, i nęciła prostota Ewangeliii ${ }^{28}$; poszukiwał jednak światopoglądu naukowego. Po drugie, zmysłowy, fantastyczny charakter tej doktryny, w której gnostyczny racjonalizm łączy się z niepohamowaną wschodnią wyobraźnią, był niezwykle bliski jego południowemu, afrykańskiemu temperamentowi. Wreszcie po trzecie, jak powiedziano wyżej, w tej doktrynie otrzymuje swoją hipostazę ów etyczny i psychologiczny dualizm, który na drodze samoanalizy Augustyn znajduje w sobie. „W cnocie ceniąc spokój - mówi Augustyn - a w występku dostrzegając przede wszystkim zakłócenie ładu, wnioskowałem, że cnota polega na pewnego rodzaju jedności, a występek - na rozdarciu. Sądziłem, że na takiej samej jedności polega racjonalność myśli, jak też istota prawdy i najwyższego dobra. W owym zaś rozdarciu dopatrywałem się, nieszczęsny, jakiejś jak gdyby substancji życia irracjonalnego, jak też istoty największego zła, które według mojego ówczesnego mniemania miałoby być nie tylko substancja, ale wręcz formą życia”, przy tym substancją niestworzona przez Boga, lecz mu współwieczna. Dobro rozumiał jako nieposiadająca płci substancję myśląca, nazywajac ją Monada, a zło - Dyadą ${ }^{29}$.

Okres manichejski błogosławionego Augustyna stanowi zjawisko bardzo pokrewne i analogiczne do pesymizmu naszych czasów. Współczesny pesymista Schopenhauer, tak jak i błogosławiony Augustyn, przenosi na postrzeganie obiektywnego kosmosu swoje subiektywne sprzeczności, tworząc hipostazę wewnętrznego rozdwojenia swojej osobowości. On również czyni złą diadę fundamentem wszystkiego, co istnieje: świat, także $z$ jego punktu widzenia, jawi się jako sprzeczny twór dwóch wrogich zasad: bezmyślnej złej woli - zasady wrogości i rozdarcia, oraz bezwolnego intelektu, którego rola sprowadza się do samej tylko pasywnej walki ze złą wola, celem wyzwolenia siebie od niej. Droga wyzwolenia u Schopenhauera jest taka, jak u Maniego, albowiem i u niego światowy kryzys dokonuje się w człowieku, który będąc najpełniejszą obiektywizacją szatańskiej

28 Zob. tegoż, Wyznania, ks. III, rozdz. 5, dz. cyt., s. 60.

29 Zob. tamże, ks. IV, rozdz. 15, s. 88. 
wolicjonalnej zasady, jest również najwyższym przedstawicielem i nosicielem światowego intelektu. Rola człowieka w systemie Schopenhauera także polega na tym, aby - uświadomiwszy sobie marność i złą naturę istnienia - wyzwolić świat od jego sprzeczności na drodze ascetycznego wyrzeczenia się siebie. U Schopenhauera, tak jak i u Augustyna, dostrzegamy identyczną zbieżność rezultatów subiektywnej refleksji zachodniego myśliciela ze zmysłowym, fantastycznym światopoglądem religii Wschodu, ten sam pociag do religijnego akosmizmu Wschodu. Jeśli bowiem buddysta Schopenhauer unicestwia całość kosmosu w nirwanie, równocześnie rozdwajając go w dualizmie istoty wszechświata i maji, zasłony złudy, to i Augustyn traci jedność kosmosu, przyjmując dwie manichejskie substancje i postrzegając wszechświat jako rezultat sprzeczności. U Schopenhauera, tak jak i u Augustyna, zachodni subiektywizm w swoim skrajnym i jednostronnym rozwoju styka się z obiektywizmem Wschodu. Ta zbieżność zdaje się zrozumiałym i całkowicie nieprzypadkowym zjawiskiem: skrajny subiektywizm i skrajny obiektywizm sprowadzają się do jednego wspólnego rezultatu - takiego mianowicie, że w jednym i drugim zatraca się umowna granica między subiektywnym a obiektywnym, między zewnętrznym a wewnętrznym. Obojętnie, czy rozpatrujemy wszystko, co wewnętrzne, jako fenomen substancji obiektywnej, czy - przeciwnie - wszystko, co zewnętrzne, jako odblask wewnętrznego, to w obu przypadkach dochodzimy do jednakowego rezultatu - stopienia się subiektywnego i obiektywnego. Nasze wnętrze przenika do obiektywnego świata, materializuje się w nim, albo też przeciwnie - nasze stany wewnętrzne znajdują swoją hipostazę w obiektywnej substancji, a wszystko, co zewnętrzne, rozumie się na ich obraz i podobieństwo. Konsekwencje sa jednakowe - w tym tkwi sekret wschodnich wpływów na zachodnią filozofię.

Usposobienie Augustyna w okresie manichejskim można określić jako głęboką mroczną rozpacz. Przyczynę takiego stanu on sam upatruje później w chwiejności swych ówczesnych wyobrażeń o Bogu ${ }^{30}$. Manichejskie bóstwo posiada z natury wspólną z nami istotę i pochodzenie, nasza dusza to cząstka owego bóstwa, i dlatego też bóstwo nie wynosi nas ponad nas samych, nie podnosi nas ze słabości i niemocy naszej natury, nie uwalnia nas od naszych cierpień. Przeciwnie - dzieli z nami naszą - indigentiam et imbecillitatem. Jeśli nasza dusza jest częścią bóstwa, to Bóg wraz z nami „psuje się przez nasza głupotę, zmienia się poprzez swój upadek i utraciwszy

${ }^{30}$ Quia non mibi eras aliquid solidum et firmum, cum de te cogitabam [,,[...] zwłaszcza, że nie myślałem o Tobie jako o czymś rzeczywistym i trwałym"] - Augustyn z Hippony, Wyznania, ks. IV, rozdz. 7, dz. cyt., s. 80 . 
doskonałość, zostaje narażony na przemoc i potrzebuje pomocy, zduszony nieszczęściem i zhańbiony niewolą"31. Od takiego bóstwa nie możemy oczekiwać zbawienia, ono samo raczej potrzebuje naszego współdziałania w swoim wyzwoleniu ${ }^{32}$, i z tego też powodu światopogląd manichejczyków wydaje się pozbawiony radości i nadziei. Augustyn pojął to i poczuł szczególnie wyraźnie, kiedy bolejąc nad śmiercią przyjaciela, szukał i nie znajdowal pocieszenia w manichejskich zasadach wiary. On sam wiernie opisuje swój ówczesny nastrój jako taedium vivendi et moriendi metus ${ }^{33}$; świadomość pustoty i jałowości teraźniejszego zostaje wzmocniona przez brak nadziei na przyszłość. „Wszystko mnie odpychało - mówi Augustyn - nawet samo światło dzienne" 34 , zbrzydło mi wszystko, prócz lamentów i łez. I dalej: kiedy próbowałem uspokoić moją duszę w fałszywym Bogu, wytworze mej wyobraźni, ona ,spadała przez próżnię i znowu mnie przygniatała. I pozostałem sam dla siebie owym miejscem nieszczęsnym, w którym nie mogłem przebywać i z którego też nie mogłem uciec. Dokądże bowiem miało serce moje uciec od siebie samego? Gdzież było takie miejsce, w którym bym sam nie dościgną siebie?" ${ }^{35}$. Szukając zbawienia w manicheizmie, znajdował w nim jedynie odbicie swoich subiektywnych sprzeczności.

W świecie, gdzie wszystko to pozór i kłamstwo, nie ma niczego obiektywnie wiarygodnego, prawdziwego. Sama nasza świadomość pełna jest sprzeczności. Jeśli wszystko na świecie - nie wyłączając nas samych - to kłamstwo i sprzeczność, jeśli nie ma jednej i pełnej prawdy, to żadne obiektywne poznanie nie jest możliwe. Tylko jeden krok dzieli dualistyczny pesymizm od rozpaczy sceptyka. I tak rozczarowany manicheizmem Augustyn wpada w sceptycyzm Nowej Akademii. Ten sceptycyzm byl jednak tylko przejściowym momentem w jego rozwoju i nie mógł całkowicie zawładnąć jego energiczną i namiętną naturą. Było to tylko czasowy, a przy tym niezbyt długi stan wahania i niezdecydowania. „Przyszło mi też wtedy do głowy - pisze Augustyn - że najrozsądniejsi ze wszystkich filozofów są tak zwani akademicy. Uznali oni, że o wszystkim należy wątpić (quod de omnibus dubitandum esse censuerant) i że człowiek nie jest zdolny do poznania

\footnotetext{
${ }_{31}$ Tegoż, De moribus ecclesiae catholicae et de moribus manichaeorum libri duo, ks. II, rozdz. 11, \ 22. [W oryginale: [...] et stultitia corrumpitur et cadendo mutatus est et amissa perfectione violatus et opis indiget et debilis morbo et oppressus miseria et servitute turpatus est].

32 Tegoż, Przeciw Faustusowi, ks. II, rozdz. 11, tłum. J. Sulowski, Warszawa 1991, s. 9-10.

${ }^{33}$ Tegoż, Wyz̧nania, ks. IV, rozdz. 6 [,[...] życie mi ciążyło jak okropne brzemię, a jednocześnie bałem się śmierci” - s. 78]. Słowa te mogłyby stać się wspaniałą charakterystyką ówczesnych nastrojów społecznych w ogólności.

34 Tamże, ks. IV, rozdz. 7, s. 79 [przyp. tłum.].

35 Et ego mibi remanseram infelix locus, ubi nec esse possem nec inde recedere. Quo enim cor meum fugeret a corde meo? Quo a me ipso fugerem? Quo non me sequerer? - tamże, ks. IV, rozdz. 7, dz. cyt., s. 80.
} 
czegokolwiek w sposób pewny”36. „Zgodnie więc z zasada, jaką się przypisuje akademikom, wątpiłem we wszystko i trwałem zawieszony między różnymi teoriami (inter omnia fluctuans). Od manichejczyków jednak postanowiłem odejść. Uważałem, że w okresie wątpienia nie powinienem pozostawać w tej sekcie, skoro tezy niektórych filozofów bardziej mi trafiały do przekonania niż jej wierzenia"37. Oczywiście nie mamy tu do czynienia z absolutnym sceptycyzmem ani w ogóle z żadnym określonym i przyjętym światopoglądem, a jedynie z uznaniem względnej słuszności filozofów sceptyków $^{38}$. Nie mylą się oni, przedkładając nad dowolne dogmatyczne usposobienie wattpienie w siły i zdolności ludzkiego rozumu. Sądzą trafniej niż inni, ponieważ są od innych pokorniejsi. Lecz jeśli człowiek nie jest w stanie poznać prawdy o swych własnych siłach, to nie wynika z tego jeszcze, że sama prawda nie istnieje. Jeśli pozostawiony sam sobie człowiek nie jest w stanie dojść do prawdy, to prawda może wyjść naprzeciw jego wysiłkom i sama mu się odkryć. Niedostępna w racjonalnym poznaniu, może stać się przedmiotem objawienia. W takim wypadku sceptycyzm zmienia się w akt pokory, w pasywne podporządkowanie się ludzkiego rozumu działaniu z góry. W istocie, sceptycyzm Augustyna był dla niego jedynie stopniem pośrednim do mistycznego światopoglądu filozofów neoplatońskich.

„Bodźcami wewnętrznymi niepokoiłeś mnie - czytamy w Wyznaniach - abym dopóty nie zakosztował uciszenia, dopóki wewnętrzny mój wzrok nie zacznie Ciebie dostrzegać bez żadnej wątpliwości"39. Dręczący stan wątpliwości i wahania był jedynie objawem niezadowalających poszukiwań i sceptycyzmu Augustyna, jedynie skutkiem jego wrodzonego mistycyzmu, który nie pozwalał mu znaleźć ukojenia w dogmatycznych konstrukcjach. Już wcześniej widzieliśmy, jak wewnętrzna wiarygodność samoczucia wynosiła go ponad sceptyczne wątpliwości ${ }^{40}$. Wszystko, co istnieje, jest przecież nieuzasadnione, lecz jestem i chcę. W rozdwojeniu mojej świadomości i woli dostrzegam jedność jako absolutny warunek, jako ideał.

\footnotetext{
${ }_{36}$ Tamże, ks. V, rozdz. 10, \19, s. 106.

${ }^{37}$ Tamże, ks. V, rozdz. 14, \25, s. 111-112.

${ }^{38}$ Por. J. Storz, Pbilosophie des hl. Augustinus, Freiburg im Breisgau 1882, s. 31 [Trubieckoj ma tu na myśli następujący fragment, zachowuję oryginalną ortografię: „Wie für Augustinus selber der Skepticismus nur ein Durchgangspunkt war, als er von den gnostischen Irrthümern des Manichäismus zur Erkenntniß der Wahrheit durchzudringen suchte, so hielt er fortan an dem Grundsatz fest, daß die Skepsis wohl berechtigt sei gegenüber den Irrthümern des Dogmatismus, daß sie aber nicht so weit gehen dürfe, alle Möglichkeit des Wissens zu läugnen und den Menschen der Hoffnung auf den Erwerb wahrer Erkenntnisse zu berauben"].

${ }^{39}$ Augustyn z Hippony, Wyznania, ks. VII, rozdz. 8, dz. cyt., s. 148.

${ }^{40}$ Zob. tamże, ks. VII, rozdz. 3, s. 139-140.
} 
Takiej jedności nie ma ani w zewnętrznej rzeczywistości, ani we mnie samym: ona wznosi się ponad wszystkim, co znajduję w mym doświadczeniu. To ideał, niepomiernie przekraczający wszystko, co ziemskie, absolutnie transcendentny. Dochodzę do niego jedynie na drodze odwrócenia się od wszystkiego, co zewnętrzne, poprzez wewnętrzną kontemplację. Jedynie wewnętrznie skupiona świadomość, która zebrała się w sobie i odrzuciła wszystko, co zmysłowe, może dojść do uznania owej jedności poza granicami naszego poznania. Wiarygodność mojej samoświadomości i mojej woli jest przy tym absolutną wiarygodnością ich transcendentnego ideału. Augustyn doszedł do takich wniosków pod wpływem lektury filozofów neoplatońskich, co sam ujawnia w swoim opowiadaniu.

Został zainspirowany przez nich do wejścia w samego siebie (redire ad me ipsum) i tak o tym mówi: „Zacząłem więc wchodzić w głębię mej istoty za Twoim przewodnictwem. Mogłem w nią wnikać, ponieważ Ty mnie wspomagałeś. Wszedłem tam i takim wzrokiem duchowym, jaki był mi dany, dojrzałem w górze, ponad owym wzrokiem, ponad moim umysłem, światłość Boga niezmienną: nie tę pospolitą światłość dzienną, którą dostrzega każde żywe stworzenie" ${ }^{\text {"41 }}$. Nie jest to już rozlane w przestrzeni, zmysłowe, manichejskie bóstwo, lecz zasada absolutnie ponadzmysłowa. Owo obiektywne, niematerialne światło, oświecające nas od wewnątrz, stanowi wyraźny kontrast dla naszej ubogiej, bezsilnej świadomości. „Schłostałeś słabość mego wzroku - kontynuuje Augustyn - przemożnym uderzywszy we mnie blaskiem (radians in me vehementer), aż zadrżałem z miłości i zgrozy. Zrozumiałem, że jestem daleko od Ciebie - w krainie, gdzie wszystko jest inaczej. I zdało mi się, że słyszę Twój głos z wyżyny: «Jam pokarm dorosłych, dorośnij, a będziesz mnie pożywał - i nie wchłoniesz mnie w siebie, jak się wchłania cielesny pokarm, lecz ty się we mnie przemienisz»”"42.

Jeśli prawda nie jest rozlana w świecie zewnętrznym i nie mieści się w przestrzeni ani w skończonej, ani bezgranicznej, to czy wynika stąd, że sama prawda nie istnieje? $\mathrm{Na}$ to pytanie mojej świadomości - mówi Augustyn - usłyszałem w odpowiedzi Twój głos, niby z daleka: Ja jestem prawdziwy i istniejący. W Boskim Ja Augustyn dostrzega nareszcie przedmiot swoich poszukiwań. Dzięki energii osobistej samoświadomości Bóstwa zostaje odbudowana utracona jedność, a pełna istota ludzka dostępuje zbawienia. Oto i jest obiektywne miejsce, gdzie człowiecze ,ja” znajduje spokój i taki wewnętrzny pokój, który uwalnia od mąk rozdwojonej świadomości. Utraciwszy Boga, błądzimy, nie znajdujemy dla siebie miejsca, a je-

41 Tamże, ks. VII, rozdz. 10, s. 150.

42 Tamże, s. 151. 
dynie w nim znajdujemy siebie, przychodzimy do siebie. „A gdzież byłem ja, gdy szukałem Ciebie? Ty byłeś tuż przede mną, ja zaś odszedłem nawet i od samego siebie. Nie mogłem siebie odnaleźć. Jakże miałbym znaleźć Ciebie?”43. Bóg jest „życiem mego życia”"44. Utraciwszy Go, tracimy pełnię naszego istnienia, pozbawiając się świata wewnętrznego. „Stworzyłeś nas bowiem jako skierowanych ku Tobie. - czytamy w Wy₹naniach - I niespokojne jest serce nasze, dopóki w Tobie nie spocznie" ${ }^{\text {"45 }}$ Znajdując Boga, budzimy się jakby z głębokiego snu. „Ocknąłem się ku Tobie i zobaczyłem, że jesteś nieskończony, ale w zupełnie inny sposób, niż sobie przedtem wyobrażałem. A poznania tego nie zawdzięczałem zmysłom. Przypatrzywszy się innym rzeczom, pojałem, że Tobie one zawdzięczaja istnienie i że w Tobie istnieją wszystkie rzeczy skończone, lecz w inny sposób, niż przedtem mniemałem: istnieja w Tobie nie jak w przestrzeni, lecz dlatego, że Ty dzierżysz wszystkie rzeczy w Twojej prawdzie"46.

Przejmując tym sposobem pierwiastki neoplatońskie, Augustyn nie był jednak w tym okresie neoplatonikiem. $\mathrm{Na}$ pierwszym planie znajduje się dla niego praktyczne, życiowe zadanie, a spekulatywny, mistyczny ideał filozofów neoplatońskich nie zadowala go z powodu swej abstrakcyjności. Transcendentna "Jednia" neoplatoników nie przezwycięża rozdwojenia ziemskiej rzeczywistości, a kontemplatywny mistycyzm ich filozofii łączy się z głębokim dualizmem. W neoplatonizmie istnieje dramatyczny kontrast między abstrakcyjną boską jednością - transcendentna, ponadzmysłową i absolutnie nie do ucieleśnienia - a wrogą i obcą boskiej rzeczywistości materia. Materia stanowi zasadę niedoskonałości i zła w świecie - sprzeciwia się Bóstwu. Nie jest przez nie stworzona, jednak istnieje odwiecznie i nie może być ani przemieniona wewnętrznie, ani zniszczona. Między niebem a ziemią, między Boskim a materialnym trwa nieprzejednana wrogość; rozdarcie skłóconych zasad, walka i rozdwojenie leżą u fundamentów wszelkiego istnienia. Rzecz jasna, że taki system nie jest w stanie przezwyciężyć manichejskiego pesymizmu, a Augustyn nie po to porzucił wschodni dualizm, aby pogrążyć się w dualizmie greckim. Dostrzegliśmy, że dążenie do wybawienia się od fatalnego dualizmu to główny nerw jego filozofii. Zadanie filozofii - jak już mówiłem - to dla niego jednocześnie zadanie praktyczne, religijne, zadanie zbawienia. Świat boski stanowi dla niego przede wszystkim obiektywną zasadę zbawienia. Skoro

\footnotetext{
43 Tamże, ks. V, rozdz. 2, s. 94.

44 Wyrażenie, które u Augustyna pojawia się nieustannie [W oryginale: vita vitae meae].

45 Augustyn z Hippony, Wyznania, ks. I, rozdz. 1, dz. cyt., s. 23.

46 Tamże, ks. VII, rozdz. 14, 15, s. 153-154.
} 
„Jednia" neoplatoników to abstrakcja, zaprzecza ona wszystkiemu, co indywidualne i jednostkowe, a istota ludzka może osiągnąc jej kontemplację jedynie na drodze samounicestwienia w ekstazie. W takim bezosobowym boskim kosmosie jednostka nie znajduje dla siebie miejsca ani spokoju. Bezosobowe bóstwo wydaje się obojętne i obce człowiekowi, nie ocala go ani nie zbawia. Przedmiotem poszukiwań Augustyna jest Bóg zainteresowany zbawieniem człowieka, Bóg, w którym ludzki, jednostkowy pierwiastek nie ulega zniszczeniu, ale zostaje zachowany, otrzymując wyższy sens i punkt odniesienia. Z tego powodu neoplatonizm Augustyna uzyskuje w tym czasie chrześcijańskie zabarwienie. Miejsce abstrakcyjnej „Jedni” Plotyna i Porfiriusza zajmuje energia osobistej samoświadomości Bóstwa, które wchodzi z człowiekiem w dialog, odpowiadając na jego poszukiwania. Aby uwolnić nas od rozdwojenia naszej ziemskiej rzeczywistości, aby wybawić nas od cierpienia i śmierci, Boska jedność musi stać się faktem naszej rzeczywistości i przeniknąć ją soba. Aby zbawić człowieka, Bóg powinien wejść $z$ nim w bezpośredni, intymny kontakt, twarzą $\mathrm{w}$ twarz - jednym słowem - uczłowieczyć się. Aby zbawić ludzkość jako rodzinę, jako wspólnotę społeczną, Boski porządek powinien ucieleśnić się w powszechnej strukturze społecznej. Taki jest logiczny proces, popychający Augustyna od neoplatonizmu ku chrześcijaństwu i ku Kościołowi.

Od neoplatoników odpycha go właśnie brak człowieczeństwa w ich wyobrażeniach o Bóstwie. Augustyn w całości przyswaja sobie ich naukę o wiecznym Boskim Logosie, parafrazując ją w znanych słowach Ewangelisty Jana ${ }^{47}$. Lecz te głębokie spekulacje neoplatoników, w oczywisty sposób nader zgodne z nauką chrześcijańska, nie zadowalaja przyszłego ojca Kościoła, ponieważ obca jest im idea wcielenia, bogoczłowieczeństwa, która jako jedyna jest w stanie pokonać dualizm, pogodzić to, co ludzkie i ziemskie, z boskim. Bóstwo neoplatoników nie zniża się do ludzkiej niemocy, nie przychodzi na pomoc cierpiącym i, przebaczając, nie zdejmuje z nas ciężaru grzechów.

Równolegle z neoplatonizmem Augustyn doświadcza również innego potężnego oddziaływania, które z nieodpartą siła pociąga go w tym samym kierunku. W czasie, kiedy mistyczny ideał przemienia się dla niego w praktyczny imperatyw, kiedy poszukuje konkretnego ziemskiego ucieleśnienia boskiej jedności, styka się z potężną osobowością Ambrożego. Nie ma potrzeby, abym wchodził tu w szczegółową charakterystykę tego wielkiego hierarchy Kościoła. Wystarczy zaznaczyć w jego charakterze te cechy, które tak czy inaczej oddziałały na światopogląd jego genialnego

47 Tamże, ks. VII, rozdz. 9, s. 148-149. 
ucznia. Można powiedzieć, że Ambroży jest konkretnym uosobieniem potężnej organizacji kościelnej. W osobie Ambrożego idea chrześcijańska przyjmuje postać nieprzezwyciężonej, miażdżącej siły: nie można znaleźć wyraźniejszego wizerunku wszechmocnej łaski, która triumfuje nad najpotężniejszymi przejawami ludzkiego zła, podejmuje walkę z najwyższą ludzką władza. Ambroży uosabia triumf przedstawiciela idei religijnej nad najwyższym wymiarem ludzkiej potęgi. Wychodzi on zwycięsko z konfliktu z ariańską władczynią i obraca w proch osobowość tak niebagatelna jak Teodozjusz Wielki. Równocześnie mamy tu do czynienia z ucieleśnieniem kontrastu między bezsilnością i nędzą władzy świeckiej w osobach słabych imperatorów w rodzaju Gracjana i Walentyniana II a wielkością duchownej władzy przedstawiciela kościoła. Ten święty pasterz, twierdząc, że to państwo trwa w Kościele, a nie Kościół w państwie, że Kościół jest ważniejszy i potężniejszy od państwa, w rzeczywistości panuje i triumfuje nad władza świecka, wcielając się w rolę to surowego sędziego i nauczyciela, to opiekuna i piastuna ograniczonych umysłowo imperatorów ${ }^{48}$. Z uwagi na swój charakter i skłonności wydaje się być pod wieloma względami poprzednikiem wielkich średniowiecznych papieży, zwiastunem Grzegorzy i Innocentych. Augustyn poszukuje konkretnego historycznego ucieleśnienia idei religijnej i oto idea chrześcijańska pojawia się przed nim pod postacia energii wszechstronnej działalności praktycznej. Poszukuje obiektywnej zasady zbawienia, boskiej jedności jako obiektywnej normy ludzkiego życia i działalności, i styka się z potężną powszechną strukturą Kościoła, reprezentowana przez niebagatelną osobowość wielkiego biskupa. Jednak Ambroży imponuje Augustynowi nie tylko swym zewnętrznym autorytetem, wielkością i potęga. Jednoczy on w sobie autorytet kościelny z wykształceniem naukowym, jego słowo brzmi nie tylko jako zewnętrzny nakaz, ale posiada siłę wewnętrznego przekonywania. Ambroży jest uosobieniem Kościoła będącego nie tylko zewnętrzną wspólnotą, lecz także rozumnym porządkiem, wspólnotą wewnętrzną i organiczną. Słuchając go, Augustyn po raz pierwszy nabiera przekonania o możliwości rozumowego wyjaśnienia nauki chrześcijańskiej, upewnia się, że nie ma zasadniczej sprzeczności pomiędzy wiedzą rozumową a obiektywnym objawieniem ${ }^{49}$.

W osobie Ambrożego chrześcijański ideał staje się dla Augustyna wszechstronnym panowaniem boskiego porządku nad życiem - jako wszechpotężny Kościół posiadający władzę nad jednostkami i społeczeń-

${ }^{48}$ Dla pełniejszej charakterystyki Ambrożego por. A. De Broglie, L'Eglise et l'Empire Romain au IVE siècle, Paris 1906, t. III, cz. 2, [rozdz. V].

49 Zob. Augustyn z Hippony, Wyznania, ks. VI, rozdz. 4, dz. cyt., s. 117-119. 
stwem, jako teokracja, w której żywioł świecki pochłonięty jest przez duchowny. Jak już powiedziano, wrażenie, które wywarła na Augustynie osobowość Ambrożego, pozostawiło niezatarty ślad na światopoglądzie tego pierwszego. Augustyński ideał chrześcijaństwa na zawsze związał się z tym wrażeniem, pozostał do końca ideałem teokratycznym. Takiemu ogromnemu wpływowi Ambrożego na Augustyna sprzyjało głębokie pokrewieństwo charakterów obu świętych pasterzy. Jak już wspomniano wyżej, centralne doświadczenie całego życia Augustyna stanowi kontrast grzechu i wszechmocnej łaski. Jeśli zaś łaska jest wszechmocna, a ludzka wola marna i nędzna, to wynika stąd, że aby człowiek mógł się zbawić, musi złożyć ofiarę ze swej wolności i całym swym istnieniem oddać się obiektywnej łasce. Poszczególne indywiduum powinno zniknąć w jej obiektywnym porządku, człowiek uzyskuje swoje znaczenie i swój sens jedynie jako narzędzie umożliwiające nastanie powszechnych rządów Bożych. Wszechmocnej łasce odpowiada będący jej ucieleśnieniem wszechwładny Kościół. Takim sposobem wpływ Ambrożego współbrzmi z centralnym motywem światopoglądu i życia naszego ojca Kościoła.

Nie będę tu referować nazbyt dobrze znanych szczegółów przejścia Augustyna na chrześcijaństwo. Interesuje nas tutaj wewnętrzna historia jego światopoglądu, a nie zewnętrzne zdarzenia z jego życia. Wystarczy jedynie odnotować tutaj jedną charakterystyczną cechę owego nawrócenia. Sam Augustyn przypisuje ten głęboki przewrót wewnętrzny, który się w nim dokonal, zewnętrznemu cudowi. W momencie, kiedy jego cierpienia i męki z niezadowalających poszukiwań nasilaja się do granic wytrzymałości, wstrząs wewnętrzny wyprowadza go ze stanu wątpliwości i wahań. Słyszy głos mówiący: tolle et lege (weź i czytaj), a słyszy go uszami ciała, lecz źródła tego głosu upatruje w objawieniu z góry. Za jego namową otwiera Pismo Święte, natrafia w nim na tekst odpowiadający na jego poszukiwania i odnosi go do siebie, co ostatecznie przesądza o nawróceniu ${ }^{50}$. W najwyższym stopniu charakterystyczne jest dla Augustyna to, że widzi w swoim nawróceniu jakby gwałt łaski na bezsilnej istocie ludzkiej. Laska okazuje się nieodparta siłą działająca na człowieka od wewnątrz i z zewnątrz - nie tylko poprzez pobudzenia wewnętrzne, ale również przez wstrząsy zewnętrzne. Doprowadza nas ona do obiektywnej jedności nie tylko na drodze wewnętrznego oświecenia naszego umysłu i serca, lecz także na drodze zewnętrznej przemocy. Wspomniane opowiadanie zamieszczone w Wyznaniach zostało napisane mniej więcej czternaście lat po nawróceniu Augustyna z punktu widzenia w pełni rozwiniętej nauki o łasce i gotowi je-

50 Zob. tamże, ks. VIII, rozdz. 12, s. 182-184. 
steśmy zgodzić się ze stanowiskiem Gastona Boissier ${ }^{51}$ i Adolfa Harnacka ${ }^{52}$, którzy twierdza, że w tym czasie Augustyn był skłonny opisywać swoje nawrócenie jako proces bardziej nagły, niż było to w rzeczywistości. Nagłego nawrócenie nie było, ale przeciwnie - było ono przygotowane przez cały poprzedzający je rozwój naszego bohatera. Nabrawszy dystansu, mógł on postrzegać swoją przeszłość w nowym świetle i mógł pomylić się w ocenie takich czy innych zdarzeń, lecz nikt nie posądza go o to, aby te zdarzenia zmyślił. Dla nas z kolei faktem najwyższej wagi pozostaje to, że sam Augustyn łączy swoje nawrócenie $\mathrm{z}$ zewnętrznym cudem. Już w tym przeżyciu skrywa się pretekst dla rozwiniętej później przez niego fantastycznej teorii łaski, zgodnie z którą działa ona na naszą wolę nie tylko z mocą wewnętrznej konieczności, lecz także jako zewnętrzne fatum, a nasza wola zamienia się w mechaniczne narzędzie wypełniające jej zrządzenia.

Prześledziliśmy formowanie się światopoglądu Błogosławionego Augustyna i doszliśmy do punktu, gdzie utrwala się on i ostatecznie utwierdza na chrześcijańskim fundamencie. Przyglądając się nauce zbudowanej przez niego w oparciu o tenże właśnie fundament, dostrzeżemy, że przeszłość nie znikła w niej bez śladu i że elementy określające rozwój Augustyna-poganina utrzymują się nadal w jego świadomości chrześcijańskiej. Właśnie ta pogańska przeszłość dostarcza nam klucza do zrozumienia systemu religijno-filozoficznego tego wielkiego nauczyciela Kościoła.

Rozwój Augustyna, jak mogliśmy przekonać się na podstawie powyższych rozważań, zatoczył pełne koło. Po długim błądzeniu powrócił do punktu wyjścia - do chrześcijańskiego światopoglądu jego matki. Przy głębszym wpatrzeniu się w ten światopogląd dostrzeżemy, że zachowany zostaje w nim potężny filozoficzny idealizm, który przebudził się w Augustynie pod wpływem Hortensjusza Cycerona. Znajdziemy w nim również elementy manichejskie. Pesymizmowi manichejczyków przeciwstawia się tu optymistyczną teodyceę, jednocześnie zachowując część zawartej w nim prawdy: bowiem będąc optymistą w kwestii nadziei lepszego życia, Augustyn zachowuje - całkowicie zgodny z chrześcijaństwem - pesymistyczny stosunek do życia ziemskiego. Zachowawszy jednak elementy prawdy zawarte w manicheizmie, nie uwalnia się całkowicie od jego kłamstwa. Przystępując więc po swoim nawróceniu do walki z dawnymi błędami, Augustyn broni, wbrew manicheizmowi, jedności boskiego porządku wszechświata. Przeciw dwóm bogom głoszonym przez naśladowców Maniego rozwija naukę konsekwentnie monoteistyczna, racjonalistycznemu

${ }^{51}$ Zob. G. Boissier, La fin..., t. I, ks. III, rozdz. 3, dz. cyt., s. 338-342.

${ }^{52}$ Zob. A. Harnack, Dogmengescbichte, t. III, dz. cyt., s. 84. 
subiektywizmowi manichejczyków przeciwstawia obiektywny autorytet Kościoła. Szukając ocalenia od rozdwojonego wszechświata, rozwija naukę o idealnej jedności powszechnego planu, zawartego od wieków w boskiej świadomości. Rozdwojonej ludzkiej świadomości Augustyn przeciwstawia obiektywne objawienie. Lecz nawet prowadząc spory, nie uwalnia się on w pełni od wpływu swoich przeciwników, a nieuświadomiony manicheizm nie przestaje przejawiać się w jego światopoglądzie. W nauce Augustyna zło nie ogranicza już Bóstwa od zewnątrz, ale zostaje włączone w powszechny plan jako konieczny moment Boskiej predestynacji, wynikający logicznie z faktu uzewnętrzniania się Boskiej myśli o stworzeniu. Zło przestaje być zewnętrzną granicą bóstwa, lecz zamiast tego staje się wewnętrzną koniecznością dla boskiej woli, stanowi ono konieczny moment samoobjawiania się boskiej myśli - jak ciemne tło, na którym zarysowuje się piękno i dobroć boskiej myśli o stworzeniu. Zło, będące egoizmem stworzenia, nie zostaje zwyciężone wewnętrznie w potencji, lecz przemocą wciśnięte w powszechny plan, aby pełniło rolę koniecznego środka do obcego mu celu dobra. Augustyn nie mógł nigdy zupełnie przezwyciężyć manichejskiego dualizmu i jedność ta, którą mu przeciwstawia, jest jednością za cenę przemocy, jest jednością zewnętrznąa

Zagłębiając się dalej w światopogląd naszego ojca Kościoła, znajdziemy w nim i ten sceptycyzm, który - jak zobaczyliśmy - wyraża się w pokorze umysłu, w świadomości niezdatności człowieka do poznania prawdy o własnych jedynie siłach. Nie trzeba nawet wspominać, że w światopoglądzie Augustyna zostaje zachowany mistyczny ideał neoplatoników; podobnie jak u nich również i tu wszystko, co istnieje, rozważa się sub specie aeterni, odnosząc wszystkie poszczególne rzeczy do ich wiecznej ponadzmysłowej idei. Z tego też powodu - jak już powiedzieliśmy wyżej - nosi on na sobie znamię potężnego wpływu Ambrożego.

Te elementy światopoglądu naszego ojca Kościoła po części są koniecznymi momentami świadomości chrześcijańskiej, po części zaś zawierają w sobie domieszkę kłamstwa, charakterystyczną dla tej formy chrześcijaństwa, która przejawiała się w jego dziełach.

Każdy, kto nie otrzymuje chrześcijaństwa za darmo, dla kogo nie jest ono odziedziczonym darem, a kto dochodzi do niego rozumem i wola na drodze wolnych poszukiwań, nieuchronnie doświadcza idealistycznych porywów młodości, a także rozpaczy pesymistów i sceptyków: aby uwierzyć w mistyczny ideał chrześcijaństwa, trzeba razem z pesymistami stracić

53 Z tego też powodu, jak zobaczymy dalej, Augustyński pesymizm obok pierwiastka chrześcijańskiego zawiera w sobie domieszkę manichejskiego fałszu. 
wszelką nadzieję odnośnie do ziemskiej rzeczywistości; lecz aby podporządkować się Kościołowi, trzeba razem ze sceptykami uwolnić się od racjonalistycznej zarozumiałości i pychy rozumu. Aby być chrześcijaninem, trzeba uwierzyć w ponadzmysłową ideę i uznać nad sobą Boski autorytet. Tak oto poszczególne momenty rozwoju Augustyna są do pewnego stopnia koniecznymi momentami w chrześcijaństwie, a jego Wyznania można nazwać fenomenologią chrześcijańskiej świadomości.

Lecz światopogląd naszego ojca Kościoła - jak już powiedzieliśmy i o czym przekonamy się później - zawiera w sobie niemało subiektywnego i lokalnego kłamstwa. Mówiliśmy już o tym, że nie przezwyciężył on w pełni manichejskiego dualizmu i że jedność, która przeciwstawia poglądom naśladowców Maniego, jest jednością za cenę przemocy, zewnętrzną. Ta ostatnia okoliczność wywołała niezliczone następstwa nie tylko dla samego Augustyna, lecz i dla całej zachodniej formy chrześcijaństwa, która zrodził i ufundował.

Jak już mówiliśmy na początku tego rozdziału, dla epoki Augustyna charakterystyczne są zderzenie i walka dwóch przeciwstawnych biegunów - Kościoła z jego jednością i atomowej, odosobnionej istoty ludzkiej. Powstaje pytanie, co zachodnie łacińskie chrześcijaństwo mogło przeciwstawić poszukiwaniom jednostki i anarchistycznemu indywidualizmowi dwóch społeczeństw? Odpowiedź znajdujemy w systemie Augustyna. Wolności indywidualnej przeciwstawia on przemoc łaski, bezładowi i chaosowi - jedność Boskiego planu jako zewnętrzny porządek obejmujący całe istnienie, który nie usuwa zła i egoizmu, ale podporządkowuje je swoim celom. Boska jedność jako uniwersalne prawo wszystkiego, co jest, i norma idealna wszystkiego, co być powinno, jako przyczyna sprawcza i konieczny cel wszelkiego istnienia - oto fundamentalna myśl Augustyna konsekwentnie założona przez niego u podstaw całego jego systemu. Nie jest to jednak jedność dobrowolna, w której wolne Bóstwo wchodzi w związek z wolnym stworzeniem, lecz jedność abstrakcyjna, w której Bóg jedynie od zewnątrz panuje nad światem - jedność wymuszona, za cenę przemocy.

Zwiastun i prorok średniowiecznego katolicyzmu - Augustyn mieści w sobie do pewnego stopnia tak pozytywne, jak i negatywne jego aspekty.

W momencie nawrócenia Augustyna obecne są już wszystkie elementy jego chrześcijańskiego światopoglądu, a wszystko, co następuje potem, to jedynie rozwój i zastosowanie tych zasad, które już w tamtym czasie dojrzały w jego świadomości. Dokonując przeglądu wytworów jego pisarskiej działalności, zauważymy trzy stadia rozwoju jego nauki, odpowiadające 
jego walce $z$ trzema chrześcijańskimi herezjami ${ }^{54}$ - manicheizmem, donatyzmem i pelagianizmem: 1) przeciwko manichejczykom rozwija nauczanie o obiektywnej jedności powszechnego planu, a ich racjonalizmowi przeciwstawia jedność autorytetu Kościoła; 2) przeciwko donatystom pryncypium jedności powszechnego ładu zostaje dookreślone jako unitas ecclesiae; kościelnemu partykularyzmowi donatystów przeciwstawiony zostaje katolicki uniwersalizm; 3) przeciwko pelagianom, zaprzeczającym łasce, zostaje potwierdzona jedność w działaniu łaski jako obiektywnej zasady zbawienia, jedność w powszechnej predestynacji, triumfującej nad indywidualną ludzką wolnością. We wszystkich trzech stadiach jedno i niezmienne pryncypium - idealna jedność - zostaje dookreślone jako architektoniczne pryncypium wszechświata, jako pryncypium społecznej organizacji i jako sens subiektywnej ludzkiej wolności. Rozwijając poszczególne aspekty swego nauczania przeciwko herezjom, zaprzeczającym takim czy innym aspektom chrześcijaństwa, Augustyn sumuje swoje nauczanie i dopełnia je właśnie w sporze z poganami. Tutaj ideał naszego myśliciela uzyskuje najpełniejszy wyraz i zostaje sformułowany jako Civitas Dei, jako powszechna wszechświatowa jedność rządów Bożych.

\section{/// Augustyn - apologeta teokratycznego ideału zachodniego chrześcijaństwa}

Ramy chronologiczne działalności pisarskiej błogosławionego Augustyna wyznaczaja trzy wielkie wydarzenia historyczne. Działalność ta rozpoczyna się za panowania Teodozjusza Wielkiego, w chwili ostatniego zjednoczenia państwowego obydwu części Imperium Rzymskiego i w przeddzień jego ostatecznego rozpadu; osiaga swoje apogeum w momencie zdobycia Rzymu przez Gotów pod wodzą Alaryka i kończy się w chwili podboju Afryki przez Wandalów, który rozpocząl się krótko przed śmiercią Augustyna. Zbieżność początku, apogeum i końca działalności wielkiego ojca Kościoła z trzema wielkimi wydarzeniami w świecie nie jest rezultatem zwykłego historycznego przypadku. Dla światopoglądu Augustyna nieprzypadkowe wydaje się to, że na samym początku jego działalności pisarsko-apologetycznej rozpada się zjednoczone przez Teodozjusza Imperium

\footnotetext{
${ }^{54}$ Trubieckoj przychyla się do popularnego jeszcze w XX w. poglądu, że manicheizm jest herezja w obrębie chrześcijaństwa - stąd mamy sformułowanie „trzy chrześcijańskie herezje”. Dopiero XX-wieczne badania pokazały, że to odrębny system religijny czerpiący - w niektórych swych odmianach - inspirację z chrześcijaństwa. Zob. Britannica Encyclopedia of World Religions, Chicago 2006, s. 689-690, hasło: „manichaeism” oraz Encyklopedia katolicka, t. XI, Lublin 2006, s. 11431148, hasło: „manicheizm” [przyp. tłum.].
} 
Rzymskie. Z powodu tego wydarzenia pojawił się kolejny problem, jak zachować jedność rzymskiej wspólnoty kulturowej wbrew rozpadowi jedności państwowej. Od tego momentu rzymska jedność ostatecznie przestała być jednościa państwowa, istnieje jednak nadal już jako jedność kościelna; unitas Romana zachowuje się tylko jako unitas ecclesiae, unitas catholica. Stąd wypływa wniosek, że podupadające społeczeństwo może ocalić swoja jedność jedynie w uniwersalnej jedności Kościoła, która jako jedyna wiąże ze sobą Wschód i Zachód; że - przynajmniej w odniesieniu do tego społeczeństwa - ta uniwersalna jedność jest najwyższą zasada zbawienia. I tak - po części w odpowiedzi na wydarzenia historyczne, czasem zaś jako ich antycypacja - rozpoczyna się działalność największego z apologetów chrześcijańskiej jedności. Zgodne $z$ naszą tezą jest i to, że punkt kulminacyjny jego twórczości apologetycznej zbiega się ze zdobyciem i grabieżą Rzymu dokonanymi przez Alaryka, zniszczenie Rzymu bowiem jest wyraźnym wezwaniem do stworzenia czegoś nowego. Zdobycie Rzymu stanowi śmiertelny cios dla pogańskiej idei Rzymu, znajdującej swój wyraz w kulcie rzymskiej państwowej wszechmocy. Zwycięstwo Gotów obróciło w proch nie tylko rzymską siłę, ale i pogańską boskość Rzymu.

Zwycięstwo to, doprowadzając do unicestwienia i zniszczenia pogańskiego Rzymu, było również wyraźnym świadectwem sił żywotnych i misji Kościoła chrześcijańskiego. Oddając Rzym na pastwę ognia i miecza, wojownicy Alaryka ze czcią zatrzymują się przed chrześcijańskimi świątyniami; a pokonani znajduja w nich ocalenie i schronienie przed gniewem zwycięzców. Jedynie Kościół ostał się wśród powszechnego upadku, obracając porażkę Rzymu w swój największy triumf; tylko on i jego ocalałe od płomieni świątynie pozostały symbolami Rzymu - wiecznego miasta. Zniszczenie Rzymu sprawia, że znów z niebywała siła na plan pierwszy wysuwa się pytanie o to, jak ocalić rozpadającą się wspólnotę społeczną. I tak w odpowiedzi na upadek starożytnej stolicy rodzi się największe dzieło Augustyna, gdzie rzymskiej idei państwowej miasta jako ,głowy świata" ${ }^{25}$ przeciwstawia się ideę obejmującego cały wszechświat państwa Bożego, gdzie chrześcijańską teokrację uroczyście ogłasza się jedynym prawdziwym, wiecznym, nie ręką ludzką uczynionym miastem. W momencie, gdy dym unosi się znad ruin pogańskiego, cesarskiego Rzymu, zostaje położony fundament Rzymu chrześcijańskiego i katolickiego.

Niezwykle znacząca wydaje się zbieżność daty śmierci Augustyna z początkiem podboju Afryki przez Wandalów. Odcięcie od Rzymu za-

${ }^{55}$ Właśnie rzymską ideę caput mundi zdaje się mieć na myśli Trubieckoj, używając sformułowania „город вселенная” (miasto wszechswiat) [przyp. tłum.]. 
opatrującej go w chleb Afryki, będące konsekwencją tego podboju, pozbawiało Rzym niezbędnych do życia środków. Skazywało go tym samym na śmierć głodową i było prawie równoznaczne z jego unicestwieniem. Lecz jednocześnie podbój ten okazał się drogą do największego triumfu chrześcijańskiej idei teokratycznej: Kościół, jak podczas zdobycia Rzymu tak i tutaj, jako jedyny ocalał wśród płomieni. Zwycięstwo Wandalów, ugodziwszy w państwo, dawało Kościołowi nową siłę. Kościół w Afryce Północnej stawał się bowiem teraz jedynym obrońcą idei rzymskiej kultury przed barbarzyńskim światem germańskim. Inwazja arian barbarzyńców zmusiła ludność rzymską do zjednoczenia się wokół powszechnego Kościoła i - rzecz dziwna - zwycięstwo Wandalów kontynuowało duszpasterskie dzieło Augustyna, czym zadało śmiertelny cios schizmie donatystów, która do tej pory odrywała od Kościoła powszechnego większą część afrykańskiej ludności. Schizma ta, będąca przede wszystkim reakcją sprzeciwu miejscowego afrykańskiego nacjonalizmu wobec Kościoła powszechnego jako rzymskiego Kościoła państwowego i wobec rzymskich porządków w ogólności, na skutek podboju Afryki straciła swoje ugruntowanie, a tym samym jakikolwiek sens i znaczenie. Kościół katolicki przestał być Kościołem panującym dla Wandalów arian i dzięki temu mógł przyciągnąc ku sobie swoich dawnych przeciwników - donatystów. Donatyści, dla których prawdziwy Kościół był prześladowanym Kościołem męczenników, znalazłszy się pod rządami barbarzyńców - jednakowo wrogich w stosunku do wszystkich niearian - zbliżyli się we wspólnym nieszczęściu do swoich dotychczasowych wrogów - katolików. Schizma donatystów właściwie zniknęła, a na ruinach jedności państwowej odbudowana została jedność kościelna. Zetknąwszy się ze światem barbarzyńców, państwo Boże utwierdziło się i okrzepło, a apologeta kościelnej jedności umarł na progu tego nowego germańskiego świata, jakby powierzając mu kontynuowanie i dopełnienie swojego dzieła.

Pytania, wokół których krąży myśl wielkiego apologety - jak również jego odpowiedzi - zostały podpowiedziane przez wielkie wydarzenia historyczne epoki, w której żył. Wpatrując się w jego działalność apologetyczna, dostrzeżemy, że nie jest ona niczym innym jak głoszeniem rządów Bożych jako źródła powszechnych praw wszechświata i pryncypium ogólnoświatowej struktury społecznej. Stopniowe i konsekwentne zanikanie starego Rzymu i powstawanie nowego, tzn. główny proces historyczny w tej epoce, wyznacza granice czasowe działalności duszpasterskiej Augustyna. Początkiem, środkiem i końcem owego duszpasterstwa jest ideał wiecznego powszechnego miasta, zbudowanego nie na chwiejnym ludzkim fundamencie 
- podatnym na zniszczenie i klęskę - lecz na wiecznej boskiej podstawie; jest to ideał państwa Bożego.

Aby upewnić się w tym przekonaniu, spróbujemy uchwycić w jednym spojrzeniu całość działalności apologetycznej Augustyna.

Można by zapytać: co łączy ze sobą różnorakich przeciwników, z którymi przyszło zmagać się Augustynowi w obronie swej chrześcijańskiej myśli, co łączy ze sobą tak różnorodne z punktu widzenia dążeń i charakteru herezje i sekty - manichejczyków, donatystów i pelagian? Co upodabnia te chrześcijańskie herezje do rzymskiego pogaństwa, w które wymierzone jest Civitas Dei Augustyna? Wydaje się, że tak jak przeciwników Augustyna nic nie jednoczy, jak nie ma między nimi solidarności, tak również i w jego apologetycznej działalności nie ma żadnej centralnej, dominującej wartości, żadnej centralnej idei przewodniej, która scalałaby jego dzieło w jeden połączony system. Do takiego właśnie wniosku zdaje się dochodzić większość niemieckich uczonych protestanckich, w szczególności zaś Reuter $^{56}$, a w ślad za nim Harnack. „Nie można nawet mówić o systemie Augustyna” ${ }^{57}$ - wyjaśnia ten ostatni. „Największa zasługa Reutera polega na tym, że wykazał niemożliwość skonstruowania systemu Augustyna i pozbycia się sprzeczności w nim zawartych" ${ }^{58}$. Według tych uczonych gdy wielki apologeta stawał naprzeciw swych przeciwników, kierował się różnymi wartościami i zmieniał za każdym razem punkt widzenia. Prócz tego, występując w charakterze apologety kościelnych praktyk, był zmuszony często bronić istniejących obyczajów i zasad, choćby zaprzeczały jego subiektywnemu usposobieniu religijnemu. Stąd też z jego nauczania wypływa mnóstwo sprzeczności i brak w nim jakiejkolwiek spójności i jedności. $\mathrm{Na}$ przykład doktryna o wolności woli, rozwinięta przez Augustyna przeciw pelagianom, zaprzecza temu, czego nauczał na ten temat przeciw manichejczykom. Jego antypelagiańska doktryna łaski pozostaje w takiej samej sprzeczności z doktryną o Kościele, którą rozwiną przeciw donatystom. Powinniśmy więc tutaj przyjąc za wspomnianymi niemieckimi historykami, że sprzeczności u Augustyna jest rzeczywiście sporo. Nie tylko nie za-

\footnotetext{
${ }^{56}$ Hermann Reuter (1817-1889) - niemiecki teolog ewangelicki, historyk myśli filozoficznej i teologicznej starożytności i średniowiecza, profesor uniwersytetów w Greifswaldzie, we Wrocławiu i w Getyndze [przyp. tłum.].

57 A. Harnack, Dogmengeschicbte, t. III, dz. cyt., s. 91 [Chodzi o fragment: „Aus dem bisher Ausgeführten - und nur das Wichtigste ist gennant - folgt, dass von einem System Augustin's nicht die Rede sein kann, wie er denn auch kein Werk verfasst hat, welches sich mit Origens' $\pi \varepsilon \rho \grave{~} \alpha \rho \chi \tilde{\omega} v$ vergleichen liesse"].

${ }^{58}$ Tamże, s. 91, przypis 2 [W oryginale: „Es ist ein Hauptverdienst Reuter's, die Unmöglichkeit nachgewiesen zu haben, ein System Augustin's zu construiren und die Wiedersprüche, die sich bei ihm finden, zu beseitigen"].
} 
mierzamy ich zacierać, lecz postaramy się zapoznać z nimi czytelnika (przy referowaniu Państwa Bożego). Niewątpliwe jest również i to, że nauczania Augustyna nie da się przedstawić i rozpatrywać jako systemu filozoficznego, choć obecny jest w nim silny pierwiastek filozoficzny. Między filozofem a apologetą zachodzi zawsze ta wielka różnica, że filozof buduje swój własny system, podczas gdy apologeta jest obrońcą światopoglądu danego mu z zewnątrz, istniejącego i rozwijającego się niezależnie od niego, który jest historycznie wcześniejszy od samego apologety. Stąd też jedność systemu, jedność nauczania apologety zależy po pierwsze od tego, czy taka jedność istnieje w materiale, z którym ma do czynienia, a po wtóre od tego, czy kieruje się on jakąś jedną wspólną wartością, jedną wspólną ideą w swoim stosunku do tegoż materiału. Jeśli wykaże się obecność takiej jednej wspólnej wartości, to analizowane nauczanie należy uznać za system niezależnie od jego subiektywnych sprzeczności, również w takim wypadku, gdy indywidualne usposobienie apologety nie harmonizuje z bronionym przez niego pryncypium.

Co do Augustyna zaś, to zagłębiając się w jego nauczanie, stykamy się - jak już powiedziano wyżej - z wielokrotnym brakiem konsekwencji. Lecz ponieważ nie ma na świecie ani jednego ludzkiego nauczania - ani religijnego, ani filozoficznego - które byłoby nienagannie logiczne i pozbawione sprzeczności, ponieważ absolutnie logiczny system jest jedynie nieosiągalnym ideałem ludzkiego rozumu, nie można odmawiać jakiemuś nauczaniu znaczenia systemu tylko dlatego, że posiada swoje sprzeczności, w takim wypadku bowiem nie można byłoby znaleźć żadnego systemu zasługującego na swoją nazwę. Uznajemy za system każde nauczanie, które przeniknięte jest jednym wspólnym ideałem lub pryncypium, nie stanowi zaś mechanicznej kombinacji różnorodnych elementów tylko pozornie ze soba powiązanych. Aby odmówić jakiemuś nauczaniu znaczenia systemu, nie wystarczy wskazać na zawarte w nim sprzeczności - trzeba jeszcze wykazać, że te sprzeczności sa rezultatem zderzenia przeciwstawnych pierwiastków, niezwiązanych ze sobą w danym nauczaniu żadnym ideałem lub wartością, a więc że analizowane nauczanie stanowi nie organiczna jedność, lecz mechaniczną kombinację.

Co się zaś tyczy nauczania Augustyna, jeśli niektórym niemieckim uczonym wydaje się ono zbiorem sprzeczności, wiążących się ze sobą jedynie poprzez osobę ich autora, to winny temu jest nie Augustyn, lecz oni sami. Winne jest temu przede wszystkim dogmatyczne zaangażowanie, które zmusza ich do patrzenia na wydarzenia historyczne przez pryzmat ich konfesji. Liczne twierdzenia Augustyna, jak na przykład jego nauka 
o łasce, w której jest do pewnego stopnia poprzednikiem Lutra, zostaja uznane przez nich za ewangeliczne ${ }^{59}$ nauczanie i uznane za ważniejsze. Do innych jego twierdzeń, jak na przykład do jego nauki o Kościele, gdzie staje się zwiastunem katolicyzmu, odnoszą się nadzwyczaj wrogo jako do pierwiastka „wulgarnie katolickiego”. Dlatego też wymyka im się ów ścisły organiczny związek, jaki istnieje pomiędzy nauka Augustyna o łasce i jego ideałem Kościoła i w ogóle całe nauczanie wielkiego ojca Kościoła zostaje przez nich sztucznie i przypadkowo podzielone na elementy ewangeliczne i nieewangeliczne. W szczególności niektórzy uczeni - jak na przykład Reuter - nie są w stanie uchwycić jedności ideału Augustyna z powodu obranej przez nich metody badawczej - badania szczegółowego i starannego, lecz nazbyt drobiazgowego i - jeśli można się tak wyrazić - mikroskopijnego. Biorąc pod lupę dowolne nauczanie, zawsze ryzykujemy, że pogubimy się w detalach. Wyolbrzymiając znaczenie poszczególnych sprzeczności, nie będziemy nigdy w stanie zrozumieć jedności właściwej dla całości takiego nauczania. Słowa te dotyczą szczególnie całości tak wielkiej i obszernej jak nauczanie Augustyna. Aby zrozumieć jego integralność, żeby uchwycić te słowa w jednym spojrzeniu, trzeba popatrzeć na nie z pewnej odległości i z dystansu oraz postarać się pojąć je jako część składową ogólnoświatowego procesu historycznego. Tylko wtedy przestanie nam się mienić w oczach wielość różnorodnych pierwiastków wchodzących w skład interesującego nas nauczania i dostrzeżemy w nim jedność myśli i planu.

\section{$* * *$}

Przy całej swojej różnorodności przeciwnicy Augustyna stoją na wspólnym historycznym gruncie i zgadzaja się ze soba - jeśli nie w tym, co przyjmuja, to przynajmniej w tym, czemu zaprzeczaja. Wszyscy w tej lub innej formie występuja przeciwko ideałowi jednej boskiej struktury wszechświata i wspólnoty społecznej, wszyscy - tak lub inaczej - są wrogami chrześcijańskiego teokratycznego ideału, chociaż atakują go z różnych stron.

Z punktu widzenia doktryny manichejskiej - jak już wykazywaliśmy w poprzednim rozdziale - świat nie jest tworem jednego pryncypium, lecz dwóch bogów. Świat to nie zjednoczona światynia jedynego Boga, to nie Jego zjednoczone królestwo, ale płód dwóch wrogich sobie królestw. Wszechświat nie posiada jednego architektonicznego pryncypium, nie

59 Trubieckoj zdaje się tu świadomie wykorzystywać dwuznaczność rosyjskiego przymiotnika „евангелический”, który odpowiada jednocześnie dwóm polskim przymiotnikom: „ewangeliczny” (oparty na ewangelii) i „,ewangelicki” (protestancki) [przyp. tłum.]. 
ma jednorodnej struktury. Nie tylko Bóg, ale i szatan odwiecznie rządzą światem.

Zadanie chrześcijańskiego apologety względem manichejczyków polega na ukazaniu jedności struktury wszechświata, jedności światowego ładu oraz pokazaniu, że świat jest jedną połączoną całością podporządkowaną władzy jedynego Boga. Sprzeciwiając się doktrynie rozdzielającej świat na dwa wrogie sobie królestwa, należy pokazać, że tylko sam jeden Bóg króluje wiecznie. Architektoniczna jedność wszechświata, świat jako realizacja jednego przedwiecznego planu, rządy Boże jako fakt rzeczywistości wiecznej - oto kluczowy temat wszystkich antymanichejskich dzieł Augustyna. Ściśle związane z tym tematem jest w tych pracach nauczanie o autorytecie Kościoła. Prawdziwości autorytetu Kościoła dowodzi tutaj jego rozprzestrzenianie się po całym świecie, co ma symbolizować ogólnoświatową zgodę narodów (consensus gentium). Dla Augustyna Kościół posiada autorytet przedstawiciela jednego Boskiego porządku, Bożej władzy, rozciagającej się nad całym wszechświatem.

Jeśli więc manicheizm zaprzecza jedności struktury wszechświata, to schizma donatystów stanowi otwarty zamach na jedność Kościoła powszechnego, która w porządku społecznym ucieleśnia Boską jedność. Dla donatystów ziemski Kościół nie jest przestrzenią dla wszystkich, ale społecznością świętych, wybranych. Zbawcza siła Kościoła i jego sakramentów nie zasadza się na właściwych dla niego obiektywnych darach łaski, lecz na subiektywnej doskonałości sprawujących sakramenty sług. Dlatego też sakrament, sprawowany przez osobę niegodna, której wady stały się powszechnie znane, jest - z punktu widzenia donatystów - nieważny i nie zasługuje już na miano sakramentu. Zbawcza siła Kościoła jest uwarunkowana przez ofiarność jego hierarchów, a - zgodnie z tym - charakterystyczną cechą Kościoła nie jest obiektywna i powszechna struktura, lecz osobista doskonałość jego arcypasterzy. Na osobistej doskonałości arcypasterzy, czy raczej na braku jawnych wad pośród nich, opiera się - z punktu widzenia donatystów - czystość i świętość Kościoła, o którym mówi Apostoł (Ef 5,27) i określa go jako „nie mający skazy czy zmarszczki” ${ }^{\circ}$. Kościół powszechny przyniósł samemu sobie wstyd i niesławę tym, że po zakończeniu prześladowań za Dioklecjana nie tylko nie pozbył się tych pasterzy, którzy wyparli się go pod wpływem strachu i wydali święte księgi w ręce pogan, ale również nie pozbawił ich sprawowanych funkcji i pełnionych

${ }^{60}$ Brzmienie cytatu po rosyjsku to „церковью, не имеющей пятна или порока”. Słowo „порок” znaczy tyle, co „wada, skaza”, i jego też autor używa wcześniej, pisząc o koniecznym dla donatystów braku wad u arcypasterzy i innych sług Kościoła [przyp. tłum.]. 
misji. Od tego momentu Kościół przestał być oblubienicą Chrystusa „bez skazy czy zmarszczki”, a stał się społecznością zdrajców (traditores). Od tej pory sakramenty nie są już sakramentami, a jedność utraciła swą zbawcza siłę. Najbardziej charakterystyczne jest to, że dla donatystów prawdziwy Kościół - Kościół świętych i męczenników - ogranicza się do obszaru zajmowanego przez ich afrykańską społecznośćc ${ }^{1}$, w przeciwieństwie do zniesławionego zdrada „kościoła zamorskiego” (ecclesia transmarina), jak nazywano Kościół powszechny. Doktryna nie stanowi więc wyrazu osobistej zarozumiałości biskupów donatystów, lecz przede wszystkim jest wyrazem nacjonalistycznej wyższości i pychy afrykańskiej wspólnoty donatystycznej. $\mathrm{Na}$ drodze naciaganej interpretacji Pisma Świętego donatyści próbowali wykazać, że wszystkie proroctwa o Kościele dotyczyły Afryki, że właśnie Afrykańczycy są wybranym przez Boga narodem. Dlatego też Kościół afrykański, tzn. Kościół donatystów - to Kościół taki, jakim powinien być. Ideał Kościoła znajduje dla nich odzwierciedlenie w rzeczywistości, a widzialny ziemski Kościół (to znaczy: afrykańska wspólnota donatystyczna) stanowi jego doskonałe ucieleśnienie. Wszystko to wskazuje, że w istocie pod ich dogmatycznymi sformułowaniami kryje się protest punickiego nacjonalizmu przeciwko Kościołowi niezwiązanemu wyłącznie z jakimś jednym narodem, przeciwko powszechnemu Kościołowi jako takiemu. Sprzeciw donatystów wymierzony jest właśnie w pryncypium powszechnej struktury Kościoła, istniejącej obiektywnie, niezależnie od doskonałości i godności osób ją reprezentujących. Donatyści przede wszystkim sa nienawistnie nastawieni do uniwersalistycznego ideału Kościoła, który nie wyczerpuje się w żadnych widzialnych zewnętrznych przejawach, nie jest tożsamy z Kościołem w jego doczesnym, ziemskim wymiarze.

Rozumie się samo przez się, że mając na uwadze ścisłą więź i osobliwe stosunki, które w tym czasie ustaliły się między Kościołem a państwem w Zachodnim Imperium, schizmę donatystów należy uznać za ruch tyleż antypaństwowy, co i antykościelny. Zrozumiałe jest, że zachodni imperatorzy, szukający w Kościele zbawienia od własnej słabości, postanowili złączyć swój los z Kościołem, który posiadał solidniejsze uzasadnienie. Z braku możliwości zbudowania i utwierdzenia państwa na niestałym gruncie cnót punickich kapłanów-donatystów imperatorzy postanowili oprzeć się na trwalszym fundamencie obiektywnej i powszechnej struktury, położonym przez Kościół katolicki. Imperium przeniknięte legendą ogólnoświa-

${ }^{61}$ Poza Afryką donatyści posiadali niewielką liczbę zwolenników w Rzymie i niewielką gminę w Hiszpanii. Jednak wspólnoty te nie odegrały żadnej roli w historii ruchu donatystycznego czysto lokalnego, afrykańskiego. 
towej wspólnoty państwowej nie mogło zjednoczyć się z lokalnym ruchem narodowym i - na mocy rzeczywistego pokrewieństwa - musiało przylgnąć do Kościoła stanowiącego ogólnoświatową zjednoczoną wspólnotę społeczna, to jest do Kościoła powszechnego. Oto dlaczego schizma donatystów jednakowo wrogo odnosi się tak do Kościoła powszechnego, jak do rzymskiego Kościoła państwowego, tak do Imperium, jak do państwa katolickiego. W donatyzmie znalazł swój wyraz bunt afrykańskiego nacjonalizmu przeciwko rzymskiej idei uniwersalnej jedności jako takiej; i oto dlaczego pod sztandarem donatystów zgromadziły się wszystkie pierwiastki charakterystyczne dla społeczeństwa północnoafrykańskiego - rozczarowanie Kościołem rzymskim i rzymskim panowaniem. Do donatystów przyłączył się ruch circumcellionów ${ }^{62}$, istniejący jeszcze przed powstaniem donatyzmu. Nie miał on początkowo charakteru schizmy religijnej. Był to po prostu żywiołowy ruch znacznej części wiejskiej ludności Afryki powstały w sprzeciwie wobec rzymskiego systemu agrarnego, skazującego biedny lud na rolę niewolników lub kolonów i na odrabianie pańszczyzny na rzecz nielicznych potężnych właścicieli ziemskich. Gdy tylko pojawili się donatyści, circumcellioni zjednoczyli się z nimi we wspólnej wrogości wobec znienawidzonych rzymskich porządków. I w ten sposób ruch wcześniejszy od donatyzmu, powstały na kanwie niezgody na politykę agrarną, kontynuował swoje istnienie złączony $z$ donatyzmem w nowej formie chrześcijańskiej schizmy. W ogóle widzimy donatystów na czele wszystkich afrykańskich ruchów separatystycznych, w sojuszu z wrogiem Imperium - mauretańskim królem Firmusem ${ }^{63}$, ze zbuntowanym mauretańskim księciem i afrykańskim wodzem Gildonem ${ }^{64}$. Wreszcie to na ich wezwanie i w sojuszu z nimi dokonała się inwazja Wandalów, którzy stali się ich Nemezis ${ }^{65}$.

\footnotetext{
${ }^{62}$ „Wolność religijna przyniosła donatyzmowi również poważne trudności. W jego łonie bowiem wśród najniższych warstw ludności (chłopi, niewolnicy) uformowały się bandy rabujące. Grasując po całym kraju, równocześnie bronili sprawy donatyzmu przez niszczenie materialne posiadłości przeciwników. Nazywano ich «circumcelliones», ponieważ «circum cellas vagabantur» - krążyli wokół mieszkań ludzkich" - B. Kumor, Historia Kościoła, t. I, Lublin 2001, s. 182. Zacytowany fragment przedstawia nieco inną genezę ruchu circumcellionów (wedle Kumora są oni ruchem pochodnym od donatyzmu, a nie wcześniej istniejącym, który się jedynie do niego przyłączył), stanowi jednak dobrą jego charakterystykę [przyp. tłum.].

${ }^{63}$ Firmus w latach 370-375 stał na czele powstania plemion mauretańskich przeciwko władzy Rzymian. Pomimo początkowych sukcesów powstanie zostało stłumione przez wodza Teodozjusza w 375 roku, a Firmus, nie chcąc wpaść w ręce Rzymian, popełnił samobójstwo [przyp. tłum.].

${ }^{64}$ Gildon, brat Firmusa, wszczą w roku 397 kolejne powstanie przeciwko Rzymowi. Zdradzony przez Masceleza poniósł śmierć w 398 roku, a kolejne powstanie zostało stłumione [przyp. tłum.].

${ }_{65}$ Podobny opis historii schizmy donatystycznej czytelnik znajdzie w pracy: F. Ribbeck, Donatus und Augustinus oder der erste entscheidende zwischen Separatismus und Kirche, Elberfeld 1857. Por. także: F. Böhringer, P. Böhringer, Aurelius Augustinus. Bischof von Hippo, Stuttgart 1877, s. 142-232;
} 
Spór między donatystami a Kościołem toczy się w tej kluczowej kwestii, z która zmaga się cały ówczesny Zachód: jaka jest idealna struktura społeczna, zapewniająca zbawienie jednostce i społeczeństwu. Rozumie się samo przez się, że pytanie to jest szczególnie zatrważające i dotkliwe w czasie, kiedy nadciągające i narastające fale barbarzyńskich napaści na horyzoncie powodują, że nieustannie zagrożone istnienie wspólnoty społecznej i jednostki wisi na włosku.

Przez wzgląd na omówiona specyfikę ruchu donatystycznego zadanie kościelnego apologety polega na tym, aby - po pierwsze - obronić pryncypium jedności Kościoła i jego powszechnej struktury - Kościoła istniejącego obiektywnie i przynoszącego zbawienie niezależnie od indywidualnej doskonałości duchowieństwa. Po drugie, powinien wskazać na różnicę między widzialną ziemską rzeczywistością Kościoła a jego wiecznym ideałem. Apologeta, mając na względzie budowane na jego oczach państwo Boże, powinien sprzeciwić się nauce, która głosi, że owo państwo zostało już zbudowane, a w budowli widzialnego Kościoła powinien rozpoznać i ukazać jeszcze niewypełniony, lecz stopniowo realizowany idealny plan architektoniczny. Po trzecie, ponieważ na Zachodzie pryncypium jedności jest reprezentowane przez Kościół rzymski, zachodni apologeta chrześcijańskiej jedności Kościoła jest też - chcąc nie chcąc - apologeta jedności rzymskiej, jakiekolwiek by były jego osobiste sympatie i antypatie. Jako apologeta jest nie tyle budowniczym, ile obserwatorem powstającej budowli: nie proponuje jakiegoś swojego planu architektonicznego, lecz broni tego, który jest realizowany w rzeczywistości.

Taki właśnie charakter ma antydonatystyczna apologetyczna działalność Augustyna. Zbawienie jednostki i społeczeństwa tkwi w obiektywnej jedności Kościoła, która nie zależy od osobistej świętości jego członków. Kościół nie może zostać skalany przez wady swoich pasterzy, w swoim niedoskonałym ziemskim stanie nie jest społecznością świętych. Przeciwnie - wedle Ewangelii ziemski Kościół jest siecią, w którą wpada mnóstwo najprzeróżniejszych ryb - dobrych i złych; jest rolą, na której chwast rośnie razem z pszenica. Do Kościoła przynależy wielu takich, którym nie jest sądzone wejście do królestwa przyszłego wieku ${ }^{66}$, a nie ma w Nim wie-

C. Bindemann, Der heilige Augustinus, t. II, dz. cyt., s. 366-412; D. Voelter, Der Ursprung des Donatismus, Freiburg im Breisgau-Tübingen 1883. Por. także uwagi u: H. Reuter, Augustinische Studien, szkic V, Gotha 1887, s. 231-358. O związkach donatyzmu ze stosunkami społecznymi w Afryce północnej zob. interesujące spostrzeżenia w książce H. Richtera, Das weströmische Reich, Berlin 1865, s. 305. Por. także artykuł J. Junga, Zur Würdigung der agrarischen Verbältnisse in der römischen Kaiserzeit, , Historische Zetschrift", t. 42, 1/1879, s. 56.

${ }^{66}$ Jedno z określeń na królestwo niebieskie nawiązujące do wypowiedzi Chrystusa z Ewangelii Łukasza (Łk 18,29-30), a także stwierdzenia świętego Pawła z Ef 1,21 [przyp. tłum.]. 
lu takich, którzy mają do niego wejść i osiaggnąć zbawienie. Kościół jest społecznością świętych w planie przyszłego królestwa, ale do momentu strasznego sądu Bożego nie można oddzielić ziarna od plew, a Kościół ziemski pozostaje społecznością niejednorodną. Jednym słowem Kościół na ziemi w stosunku do Kościoła idealnego, Kościoła przyszłego wieku stanowi jedynie niedobudowaną budowlę. Strażnikiem jedności tej budowli jest biskup Rzymu - związany z pierwszym wśród Apostołów świętym Piotrem nieprzerwanym łańcuchem sukcesji - a Kościół antyrzymski, taki jak wspólnota donatystów, właśnie z powodu bycia antyrzymskim nie może stać się prawdziwym, powszechnym Kościołem. Takie pomysły rozwija i w niekończących się powtórzeniach wypowiada Augustyn przeciwko donatystom.

Jeśli w ten sposób donatyści - przy całej swej odmienności od manichejczyków - zgadzają się z nimi w tym, że jedni i drudzy sprzeciwiaja się zasadzie powszechnej Boskiej struktury, manichejczycy - w porządku kosmicznym, a donatyści - w porząaku społecznym, to w istocie apologeta ma względem jednych i drugich to samo zadanie. Polemika z donatystami jedynie kontynuuje to, co zostało zapoczątkowane w polemice z manichejczykami: ujawnianie teokratycznej idei zachodniego chrześcijaństwa. Wobec manichejczyków Augustyn broni rządów Bożych jako prawa wszechświata. Wobec donatystów broni Kościoła na ziemi jako doczesnego urzeczywistnienia wiecznego planu architektonicznego w ludzkim społeczeństwie, jako czasowej i niedoskonałej formy rządów Bożych.

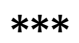

Znacznie ważniejsze od dwóch poprzednich jest trzecie stadium apologetycznej działalności Augustyna - walka z pelagianizmem. Jeśli bowiem spór z manichejczykami dotyczy jedności wszechświata, a spór z donatystami - jedności Kościoła, to pelagianie podnoszą problem samego pryncypium wewnętrznego życia religijnego jednostki i społecznego życia Kościoła - problemu łaski. Pytanie o stosunek łaski do natury ludzkiej i wolności człowieka jest jednocześnie pytaniem o samą istotę Kościoła, Kościół bowiem - zgodnie ze swoją własną nauką - to związek wolnych jednostek, zjednoczonych i zorganizowanych przez łaskę w jeden społeczny organizm. Dalej, wszystkie kościelne instytucje i sakramenty, cała jego społeczna struktura jest pewnego rodzaju związkiem łaski i wolności, tzn. już pewną odpowiedzią na pytanie o łaskę. Jednocześnie idzie tu o samą 
istotę chrześcijańskich rządów Bożych, o to, jak mają się do siebie dwa fundamentalne pierwiastki królestwa Bożego - łaska i wolność.

To inna postać owego decydującego pytania, do którego przygotowaniem były wszystkie wydarzenia tego czasu, a które „powstało z żebra” zniszczonego Rzymu - pytania o podstawy nowego społeczeństwa, któremu przeznaczono powstać na miejsce starego. W tej nieszczęsnej epoce, będąc pod wrażeniem niedawnej napaści Alaryka i rozgrabienia starożytnej stolicy, społeczność chrześcijańska łacińskiego Zachodu pytała sama siebie przede wszystkim o to, skąd ma czekać zbawienia: czy zbawi ją wszechmocna łaska Boża, znajdująca swój wyraz w kolektywnej strukturze Kościoła, czy rozbudzona energia działania jednostki? Mając na względzie światowy kryzys, który zapanował, i przygotowując się do wejścia w nowa ogólnoświatową epokę historyczna, ludzkość jakby mierzyła się i próbowała swoich sił - przeciwstawiając wolność i moc człowieka sile Bożej łaski. Naturalnie pyta sama siebie: co może człowiek ze swoją wolnością, czy ma wystarczająco dużo sił, aby uwolnić się od grzechów starego świata i stworzyć odnowione społeczeństwo, czy też do przeznaczonego mu odrodzenia potrzebuje łaskawej pomocy Boga - człowiek czy Bóg powinien być budowniczym nowego świata? Walka Pelagiusza z Augustynem rozpoczęła się w 411 roku, to jest rok po zdobyciu Rzymu i właśnie w odpowiedzi na wydarzenia, które miały miejsce. W rzeczy samej jest to spór dotyczący społecznego zadania i misji Kościoła; od takiego lub innego rozwiązania zależy cały dalszy bieg historii, bowiem w tej dogmatycznej polemice obaj przeciwnicy reprezentuja na poziomie teorii i dogmatu dwie różne zasady działające w historii świata, które walczyły ze sobą również w ówczesnym społeczeństwie i których wzajemne oddziaływanie stworzyło średniowieczną Europę. Podstawowym czynnikiem zbawienia jest dla Pelagiusza wolna jednostka, który zdobywa sobie zbawienie na drodze indywidualnego wysiłku swej własnej woli; dla Augustyna podstawową siła, zaproponowaną w kontrze do Pelagiusza, jest wszechmocna łaska, której idealnym i pełnym ucieleśnieniem jest jedynie Kościół powszechny.

Mogłoby się wydawać, że nic nie łączy pelagiańskiego odrzucenia dziedziczonego grzechu z wydarzeniami społecznymi tej epoki. W rzeczywistości taki związek jednak istnieje i jest to związek bezpośredni, bowiem obie pelagiańskie doktryny sprawiaja, że zasada skrajnie indywidualistyczna staje się podstawą życia religijnego i grozi całkowitym zburzeniem społecznej budowli Kościoła. Oba te twierdzenia zaprzeczaja jedności i wspólnocie rodzaju ludzkiego jako zorganizowanej całości. Ludzkość nie stanowi już bowiem czegoś organicznie związanego - ani poprzez jednego 
ziemskiego założyciela rodu Adama, ani poprzez twórcę jej duchowego pokrewieństwa - Chrystusa. Poszczególne indywiduum nie jest nijak związane z rodem ludzkim. Nie ma żadnego związku w przeszłości, w historii: jednostka jest wolna od grzechów swoich przodków i nie może przekazać ani swoich grzechów, ani zasług potomstwu; nie jest związana z bliźnimi więzią solidarności ani z uwagi na teraźniejszość, ani na przeszłość, ani w nadziei na przyszłość. Nie grzeszymy i nie umieramy w Adamie, grzech Adama zaszkodził tylko i wyłącznie jemu, a każdy z nas jest sprawcą swojego własnego grzechu. Z drugiej strony nie otrzymujemy zbawienia od Chrystusa, lecz zmartwychwstajemy w Nim przez dar Bożej łaski, lecz każdy z nas zbawia się poprzez swoje własne zasługi: każdy z nas jest sprawca swojego własnego zbawienia.

W tym indywidualistycznym nakierowaniu zawiera się środek ciężkości pelagianizmu. Pelagianie nie zaprzeczają łasce jako takiej, lecz wykluczaja jej jakiekolwiek społeczne oddziaływanie. Tak jak nie ma grzechu kolektywnego, rodowego, tak też i łaska nie leży u podstaw żadnej kolektywnej struktury: indywidualistyczna doktryna pelagiańska wyklucza tak solidarną odpowiedzialność ludzkości za grzech, jak solidarną jedność ludzi w zbawieniu. Pelagianie nie zaprzeczają pomocy i łasce zsyłanej przez Boga człowiekowi. Lecz łaska nie stanowi dla nich jedynego działania Bóstwa, obejmującego i ogarniającego ludzkość niczym jedyna więź. Łaska zostaje rozdzielona między wszystkich w postaci mnóstwa pojedynczych drobnych aktów Boskiej samowoli i stanowi szereg czysto zewnętrznych działań Boga na poszczególnego człowieka. Wszystkie te działania sprowadzają się do trzech głównych: stworzenia, prawodawstwa i nauczania. Stwarzając człowieka, Bóg zaszczepił w nim swoje prawo, dając mu wolną wolę, aby je wypełniał. Człowiek mógł nie grzeszyć, ale ponieważ zgrzeszył, a zaszczepienie w jego naturze świadomości prawa moralnego okazało się niewystarczające, to niezbędne było zewnętrzne napomnienie poprzez objawione przez Boga prawo i wreszcie również - zewnętrzny autorytatywny przykład i nauczanie Zbawiciela. Życie i cierpienia Chrystusa to jego indywidualne zasługi, a nie uniwersalne działanie zbawcze; poprzez śmierć krzyżową nie zostały odkupione nasze grzechy, dla Niego obce - ta śmierć może być dla nas zbawcza nie jako odkupienie, lecz jako pouczenie i przykład, mogący pobudzić nas do wypełniania prawa. Człowiek nie jest organicznie związany ze swoim Zbawca, lecz łączy go z Nim związek czysto zewnętrzny - jest uczniem i naśladowca. Każdy z nas może zbawić się nie w wyniku cudzych zasług, ale jedynie na skutek pełnego i nienagannego przestrzegania prawa. Fundament zbawienia stanowi nie miłosierdzie, 
ale Boża prawda wyrażona w formule: każdemu, co mu się należy (suum

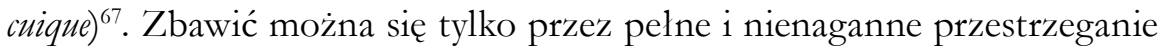
prawa: ci, którzy choćby i na jotę odstapili od prawa, bez miłosierdzia podlegają sądowi i piekłu wieczystemu.

Nietrudno zrozumieć, w jakiej relacji pozostawało to nauczanie do społecznych nastrojów i wydarzeń tego czasu. Pelagiusz, który rozpoczął swoją działalność w Rzymie kilka lat przed katastrofą 410 roku, był wstrzaśnięty głębokim upadkiem moralnym ówczesnego społeczeństwa rzymskiego. Będąc świadomym nadciagającej ze wszech stron nawałnicy, uważał za niezbędne wyprowadzenie społeczeństwa ze stanu moralnego lenistwa, apatii i rozpaczy. Chciał pobudzić chory organizm społeczny do zbawiennej dla niego reakcji. Zbawienie społeczeństwa - sądził Pelagiusz - tkwi w nim samym; aby skłonić je do działania, trzeba przede wszystkim umocnić w nim nadwątloną wiarę we własne siły. W jednym ze swoich listów ${ }^{68}$ mówi, że najlepszy sposób, aby pobudzić ludzi do działania, do dobra, sprowadza się do tego, aby ich pokrzepić i dać im nadzieję: dlatego najbardziej racjonalne nauczanie to takie, które rozpoczyna się od wskazania na siłę i moc natury ludzkiej. Najlepszą zachętę do walki, tuż przed bitwą, stanowi pokazanie siły wojska. Aby zmusić człowieka do pracy nad własnym zbawieniem, trzeba upewnić go, że zależy ono od niego samego, że leży w jego władzy. Bóg, wymagając od człowieka wypełnienia przykazań, nie wymagałby od niego niemożliwego. Jest jasne, że dał nam wolność jako niezbędny środek do ich wypełnienia. Jeśli więc zechcemy, możemy zapracować sobie na nasze zbawienie. Powinniśmy, a więc możemy - kończy Pelagiusz po kantowsku.

Nauczanie o dziedzicznym grzechu i łasce, która obdarza zbawieniem za darmo, jest $-\mathrm{z}$ tego punktu widzenia - jedynie usprawiedliwianiem apatii i lenistwa, takie nauczanie usuwa indywidualną odpowiedzialność jednostki, ponieważ nasze grzechy zrzuca się na karb odziedziczonej przez nas natury, a zbawienie staje się niezależnym od nas darem Bożym. Charakterystyczne dla doktryny pelagiańskiej wydaje się zaprzeczanie wszelkiemu ponadnaturalnemu działaniu Bóstwa na człowieka. Prawo i wolna jednostka, będąca jego wykonawca, to jedyne czynniki składające się na zbawienie. Mało tego, pelagianizm postuluje człowieka wolnego od wszelkiego ponadnaturalnego oddziaływania tylko po to, aby tym ściślej związać go

\footnotetext{
${ }^{67}$ Trubieckoj przywołuje tu popularną formułę rzymskiego prawnika z III w. Ulpiana dare cuique suum - używaną często w rozważaniach o sprawiedliwości, również kościelnych. Zob. chociażby Benedykt XVI, Oredzie na Wielkei Post 2010 r. [przyp. tłum.].

${ }^{68}$ Zob. Pelagiusz, Epistola ad Demetriadem.
} 
zewnętrznym przykazaniem: chce pozbawić swoich wyznawców nadziei na Boże miłosierdzie, aby tym gorliwiej wypełniali prawo. Pelagianizm pozostawia niezmienione wszystkie kościelne instytucje, ale zmienia je w czysto zewnętrzny prawniczy mechanizm. Zbawcza siła nie zawiera się w żadnym mistycznym i odradzającym działaniu na ludzką wolę: ludzka wola nie jest skażona grzechem pierworodnym, dlatego też nie potrzebuje odrodzenia. Zbawienie osiaga o swych własnych siłach; kościelne instytucje i sakramenty Kościoła są tylko obowiązkowymi zewnętrznymi normami prawnymi, od przestrzegania których zależy nasze zbawienie.

Warto zauważyć, że sam Pelagiusz, będący surowym i gorliwym mnichem, kierował się w swoim nauczaniu motywem ascetycznym: wierzył, że człowiek zbawia się poprzez prawe uczynki, zatem chciał skłonić swoich naśladowców do zewnętrznych ascetycznych działań. Ogromne znaczenie przyznawał ascetycznemu sposobowi życia, lecz cały sens ascezy zawierał się dla niego w wypełnieniu zewnętrznego przykazania. Na pierwszym planie znajdowały się dla niego czyny, cel praktyczny, a spory dogmatyczne uważał za głupstwa. Doktryny, które ogłosił, były zaś dla niego nie samym celem, ale jedynie środkiem, aby rozbudzić w ludziach energię do działania. Zakonnik do szpiku kości najmniej już chyba chciał być nowatorem, przeciwnie - uważał się za prawdziwego i konserwatywnego katolika, obrońcę prawa. Na wszelkie sposoby starał się prezentować swoje nauczanie jako najdawniejsze dziedzictwo Kościoła powszechnego, próbował wzmocnić je przy pomocy pełnych autorytetu imion Ojców Kościoła.

Rozumie się samo przez się, że nauczanie Pelagiusza nie zawsze jest konsekwentne i zawiera w sobie liczne sprzeczności. Rzeczywiście, jeśli człowiek zbawia się o swoich własnych siłach, jeśli w jego naturze zostało zaszczepione poznanie prawa, to może łatwo zbawić się również bez sztucznego, zewnętrznego mechanizmu Kościoła. Jeśli każdy z nas rodzi się w stanie, w jakim znajdował się Adam przed upadkiem, jeśli natura ludzka jest dobra w ziemskiej rzeczywistości, to aby dostapić zbawienia, wystarczy iść za ludzką naturą i jej naturalnymi popędami, wysiłek ascetycznej świętości jest więc czymś zbędnym i nieprzydatnym. W ten sposób doktryna pelagiańska może stać się usprawiedliwieniem laickiego usposobienia. Wywołuje świecką reakcję i wzmaga ją przez to, że zmienia religię i Kościół w absolutnie zewnętrzny i obcy człowiekowi mechanizm, a tym samym uwalnia swoich zwolenników i od Kościoła, i od chrześcijaństwa. Pelagianizm w sposób nieunikniony zmienia się w nauczanie świeckie, humanistyczne. Ascetyczne nauczanie Pelagiusza rzeczywiście przekształciło się w świecki pelagianizm jego ucznia i zwolennika - wybitnego Juliana 
z Eklanum. Julian otwarcie uznaje przyrodzoną cnotę za wystarczająca do zbawienia: sama przynależność lub nieprzynależność do Kościoła stanowi dla niego fakt zupełnie nieistotny. Już sam Pelagiusz twierdził, że prawo Starego Testamentu jest czymś wystarczającym do zbawienia, tak jak Ewangelia. A Julian, rozwijając myśl swojego nauczyciela, doszedł do wniosku, że pogańska cnota jakiegoś tam Fabrycjusza ${ }^{69}$ prowadzi do zbawienia nie gorzej niż pobożność Hioba czy pobożność w chrześcijańskim sensie tego słowa, że zbawienia tak samo łatwo dostępuje się w Kościele jak i poza nim. Asceta Pelagiusz ogromne znaczenie przypisywał wstrzemięźliwości seksualnej. Julian zaś, jako myśliciel bardziej konsekwentny, twierdził, że jeśli grzech nie jest przekazywany na drodze współżycia płciowego, to w popędzie płciowym nie ma niczego grzesznego; jeśli ludzka natura jest dobra, to w jej naturalnym popędzie nie może być niczego karygodnego, a ascetyczna wstrzemięźliwość nie stanowi zasługi. Charakterystyczna dewizą całego świeckiego nauczania Juliana jest formuła: „człowiek przez Boga wyzwolony" (bomo a Deo emancipatus). Istotnie w osobie Juliana dokonuje się emancypacja nauczania Pelagiusza od chrześcijaństwa. Julian, dla którego tekst Pisma Świętego jest autorytetem o tyle, o ile nie przeczy rozumowi, dla którego człowiek w stanie naturalnym jest najwyższym ideałem, ma rzeczywiście mało wspólnego z chrześcijaństwem i może być raczej nazwany humanistą $V$ wieku. Jego nauczanie jest refleksją o wiele bardziej pogańską, niż chrześcijańska.

Wszystko to wystarczająco demaskuje charakter pelagianizmu, będącego pogańską reakcją na gruncie chrześcijańskim. W doktrynie pelagiańskiej - szczególnie u Juliana - bez wątpienia obecny jest grecki filozoficzny pierwiastek, lecz dominująca cechą owej doktryny jest jej praktyczny charakter, a to cecha nie grecka, lecz w istocie swej łacińska, rzymska. Pelagianizm to typowe ucieleśnienie rzymskiej rzeczowej religijności, która ceni sobie zadania praktyczne, a spekulacji przydaje jedynie drugoplanowe znaczenie, dla której panowanie zewnętrznego prawa stanowi cel absolutny, a pozostałe rzeczy znaczą coś jedynie warunkowo, będąc środkami do celu. Ta

\footnotetext{
${ }_{69}$ Gajusz Fabrycjusz Luscinus był w latach 281 i 278 p.n.e. konsulem rzymskim. Tak o jego zaletach moralnych pisze historyk rzymski Eutropiusz: „Po upływie roku wysłano przeciwko Pyrrusowi [owego] Fabrycjusza, który wcześniej jako poseł nie dał się przekupić, chociaż obiecywano mu czwartą część królestwa. A że on i król obozowali w bezpośredniej bliskości, przybył do niego w nocy lekarz Pyrrusa, przyrzekając, że osobiście otruje Pyrrusa w zamian za obietnicę [jakiejś nagrody]. Fabrycjusz rozkazał odprowadzić go zakutego w kajdany do pana i powiedzieć Pyrrusowi, że lekarz uknuł spisek na jego życie. Król, pełen podziwu, miał wówczas powiedzieć: «To jest ów Fabrycjusz, którego trudniej odwieść od uczciwości niż zmienić bieg słońca»" - Eutropiusz, Brewiarium od zatożenia Miasta, ks. 2, \14, [w:] Brewiaria džiejón rzymskich, Warszawa 2010, s. 156 [przyp. tłum.].
} 
cecha aż do naszych czasów stanowi jedną z typowych właściwości rzymskiego kultu religijnego i zbliża Pelagiusza do zawsze silnej na łacińskim Zachodzie wąskoklerykalistycznej orientacji. Praktyczny charakter pelagianizmu świadczy o tym, że greckiemu pierwiastkowi filozoficznemu przypisać trzeba jedynie drugoplanowe znaczenie. Charakter i właściwości pelagianizmu sprawiają, że najbliżej mu do rzymskiego pogaństwa. Bowiem najbardziej charakterystyczna cecha rzymskiego pogaństwa, odnotowana przez wszystkich znaczących historyków współczesnych, to jego prawniczy formalizm, przekształcający związek człowieka z bóstwem i religię w mechaniczne wypełnianie prawa, w martwe zewnętrzne działanie. Całe życie religijne pogańskiego Rzymu zostało oparte na zasadzie, że człowiek zyskuje usprawiedliwienie od swoich bogów na drodze wykonania określonych zewnętrznych czynności wymaganych przez prawo; że przestrzeganie tych zewnętrznych nakazów prawa posiada zbawczy sens niezależnie od wewnętrznego usposobienia i że najmniejsze naruszenie tych wymagań jest dla człowieka zgubne, ponieważ boska sprawiedliwość nie wie, co to miłosierdzie. Stosunek bóstwa do człowieka to stosunek wierzyciela do dłużnika; człowiek otrzymuje od niego jedynie ekwiwalent swoich zasług, a od boskiego gniewu może go ocalić jedynie dotrzymanie umowy ${ }^{70}$. Wszystkie te rzymskie pogańskie zasady przeniknęły w całości do nauczania Pelagiusza, które w ten sposób stanowi nic innego jak tylko łacińską reakcję pogańską ukrytą pod zewnętrzną chrześcijańską powłoką.

Wyczerpawszy swe siły życiowe, łacińskie pogaństwo chciało żyć cudzym życiem jak pasożyt, doczepiło się do Kościoła i ożyło w formie chrześcijańskiej herezji Pelagiusza. Podobnie do pogaństwa rzymskiego pelagianizm widzi w zbiorowym życiu religijnym jedynie skupisko atomów-jednostek powiązanych ze sobą tylko zewnętrznie poprzez prawo i sztuczny mechanizm instytucjonalny. Pelagianizm wiąże rzymski uniwersalizm prawny z rzymskim religijnym indywidualizmem, który przekształca religię w prywatną sprawę o prawnym charakterze ${ }^{71}$.

Z uwagi na powyższe już zawczasu los pelagianizmu zostaje przesądzony. Pogański Rzym rozpadł się dlatego, że przestał być żywą organiczną całością, a pozostał tylko sztuczną mechaniczną konstrukcją. Pelagia-

\footnotetext{
${ }^{70}$ Por. wspaniała charakterystykę religii rzymskiej u T. Mommsena: Römische Geschichte, Berlin 1868, rozdz. XII, w szczególności s. 174-180. Zob. także G. Boissier, La religion romaine, Paris 1884, s. $1-37$.

${ }^{71}$ Ważniejsze współczesne prace o pelagianizmie: F. Klasen, Die inere Entwicklung des Pelagianismus, Freiburg im Breisgau 1882; G.F. Wiggers, Versuch einer pragmatischen Darstellung des Augustinismus und Pelagianismus nach ibrer geschichtlichen Entwickelung, Hamburg 1833; F. Wörter, Der Pelagianismus nach seinem Ursprunge und seiner Lehre. Ein Beitrag zur Geschichte des Dogma's von der Gnade und Freiheit, Freiburg im Breisgau 1866.
} 
nizm ze swoim indywidualistycznym światopoglądem nie mógł oczywiście zebrać i złożyć na nowo części zrujnowanej budowli. Doktryna pelagiańska głosiła w istocie: zbawiaj się kto może i jak może. Rozumie się samo przez się, że Kościół nie mógł przeciwstawić się barbarzyńcom z takim pelagiańskim sauve qui peut. Aby zatriumfować nad indywidualizmem germańskim, musiał on wcześniej poskromić powstały w jego własnym otoczeniu indywidualizm łaciński, pelagiański. Bieg historii świata potoczyłby się inaczej, gdyby Kościół porzucił Augustyna, a poszedł za Pelagiuszem. W rzeczywistości jednak Kościół potępił Pelagiusza i wszedł w barbarzyński świat germański jako zwarty i zorganizowany związek, jako siła organizująca, jednocząca. Za Augustynem Kościół uznał zbawienie za sprawę wspólna i społeczna, a nie za indywidualny akt ludzkiej woli; uznał za zbawienne dla siebie mistyczne działanie łaski, a nie oderwaną wolność jednostki. I przyjąwszy tę zasadę, rzeczywiście ocalił cywilizację światową od zniszczenia i śmierci, poskromił barbarzyńców i zdobył nowe pole dla szerzenia chrześcijańskiej i antycznej kultury.

Wszystkie wydarzenia tego czasu nasuwają myśl, że człowiek nie może się zbawić o własnych siłach, że ocalenie Rzymu przed barbarzyńcami może być jedynie cudem łaski Bożej. W momencie, gdy cały łaciński świat oczekuje i potrzebuje przejawów boskiej siły i władzy, Augustyn staje się apologetą łaski, czyli obrońcą chrześcijańskiego teokratycznego pryncypium przed indywidualistycznym światopoglądem Pelagiusza.

Nauczanie Augustyna, w przeciwieństwie do zadufanego nauczania jego przeciwników, opiera się na pokornej świadomości ludzkiej bezsilności, niemocy czynienia dobra. Zostaje ufundowane na obserwacji ludzkiej natury w ogóle i na obserwacji ówczesnej wspólnoty społecznej w szczególności, a przez to jest dużo bardziej trafne niż punkt widzenia Pelagiusza, który wychodzi od spekulatywnej przesłanki, od abstrakcyjnego pojęcia absolutnie wolnej osoby ludzkiej, która nigdy nie była dostępna w doświadczeniu. Za Augustynem stoi historyczne doświadczenie ówczesnego społeczeństwa, które boleśnie odczuło własną bezsilność. Wierzy on w siłę Boga, która przejawia się w uległości ludzkiej woli; jest do głębi przekonany, że człowiek nie może wysłużyć sobie własnego zbawienia, i głosi dar zbawienia, dokonującego się za sprawą miłości i łaski Bożej bez względu na jakiekolwiek wcześniejsze zasługi człowieka. Czyny zaś, które nazywamy zasługami i którymi się chełpimy, są jedynie skutkiem owego daru Bożego, bez którego żadne poruszenie naszej woli w kierunku dobra nie jest możliwe. Bóg nie tylko daje przykazania, ale również porusza naszą wolę, abyśmy te przykazania wypełnili. Wzajemny związek ludzkiej woli i łaski naj- 
lepiej jak tylko można zostaje wyrażony w sławnej modlitwie Augustyna, która skusiła również Pelagiusza: „Udziel tego, co nakazujesz - i co chcesz, nakazuj" "72 (Da quod jubes, et jubeo quod vis). Nie tylko nasze czyny, ale i sama nasza wiara, zarówno w swoim rozwoju, jak i u swego początku, jest dziełem łaski. „Bóg pobudza naszą wiarę, wywołując ją w przedziwny sposób w sercach naszych" ${ }^{\prime 73}$. Nie tylko daje nam siłę do tego, aby czynić dobro, ale wzbudza w nas również samo pragnienie dobra. Uprzedza naszą wolę w jej poruszeniach ku dobru. Potrzebujemy pomocy łaski w każdym działaniu i bez niej nie możemy uczynić nic dobrego. Laska prowadzi nas od kołyski aż po grób, towarzyszy każdemu krokowi naszego życia duchowego, oświeca od wewnątrz nasz umysł i serce, poucza nas i pomaga nam działać, poprzedza nasze życie duchowe i podąża za nim w procesie stopniowego rozwoju duchowego. Działanie łaski nie ogranicza się do jakichkolwiek zewnętrznych przejawów, lecz jest $z$ istoty swej czymś tajemniczym, mistycznym. Przez łaskę Augustyn rozumie w istocie ten tajemniczy akt, w którym Bóg objawia siebie człowiekowi, działanie niepodzielnej Trójcy na umysł i wolę człowieka; bowiem Ojciec napomina nas i uczy w naszym wnętrzu, abyśmy przyszli do jego Syna i napełnili się Duchem i miłością. Takie pełne łaski postępowanie nie sprowadza się do relacji Boga z osamotniona jednostka, lecz posiada charakter społeczny i ma za swój przedmiot ludzkość jako jeden rodzaj, jako wspólnotę społeczną. Człowiek nie został w kwestii zbawienia pozostawiony sam sobie, bowiem więź solidarności łączy go z całym rodem ludzkim. Łączy go z jego bliskimi przyrodzona więź, biorąca swój początek od wspólnego ojca rodzaju ludzkiego Adama. Przez niego też łączą wszystkich wspólne więzy grzechu. Adam jest dla Augustyna uosobieniem naszej wspólnej społecznej natury i z tego też względu grzech Adama stanowi dla niego nie tylko akt pojedynczej ludzkiej woli, ale czynnik o charakterze społecznym, rodowym. „Wszyscy byliśmy w nim samym, kiedy byliśmy tylko nim jednym". Nie istnieliśmy jeszcze wtedy jako odrębne jednostki (singillatim), lecz już byliśmy jako jedna natura w nasieniu ojca całego rodzaju (natura seminalis) i odziedziczyliśmy po nim grzeszny charakter naszej natury ${ }^{74}$. Po drugie, pojedynczego człowieka łączą z ludzkością również więzy łaski, która jednoczy wszystkich uczestników zbawienia w jedną społeczną całość w duchowym założycielu rodzaju ludzkiego - Chrystusie. Bowiem idealny cel procesu łaski zawiera się

\footnotetext{
${ }^{72}$ Augustyn z Hippony, Wyznania, ks. X, rozdz. 29, dz. cyt., s. 305.

${ }_{73}$ Tegoż, Przeznaczenie świetych, [w:] tegoż, Łaska, wiara, przeznaczenie, tłum. W. Eborowicz, Poznań 1970, s. 268.

${ }^{74}$ Zob. najbardziej klasyczny fragment dotyczący grzechu pierworodnego: Augustyn z Hippony, O państwie..., ks. XIII, rozdz. 14, t. II, dz. cyt., s. 99.
} 
w tym, aby wszyscy wybrani stali się zjednoczonym ciałem Chrystusowym lub - jak wyraził to Augustyn - jednym Chrystusem ${ }^{75}$. Grzechowi o charakterze społecznym zostaje przeciwstawione społeczne działanie laski na ludzkość jako rodzaj, jako jeden połączony organizm. Sam Augustyn mówi o swojej doktrynie łaski, którą był zmuszony rozwinąć przeciwko pelagianom, że zanim powstała ta herezja zaprzeczająca łasce, nie było potrzeby tworzenia takiej teologicznej teorii. Bowiem same dzieła Kościoła, jego modlitwy i sakramenty świadczą o tym, co rozumie on przez łaskę ${ }^{76}$. Cała Modlitwę Pańską można streścić w słowach „Udziel tego, co nakazujesz”; a kościelna praktyka chrzczenia niemowląt „na odpuszczenie grzechów” świadczy o grzechu pierworodnym, który ich dotyka, nie można bowiem zakładać, że niemowlę posiada jakiś grzech indywidualny.

Według Augustyna podstawową doczesną formą działania łaski jest społeczne życie Kościoła na ziemi, zaś jego koniecznym i bezwarunkowym celem jest społeczna jedność wybranych w Chrystusie, jedność wiecznego państwa Bożego.

\section{$* * *$}

Jak wynika z tego, co powiedziano wyżej, działalność apologetyczną Augustyna przenika jedna centralna idea, jeden historyczny motyw. Teokracja - jako prawo całego wszechświata, jako pryncypium architektonicznej jedności Kościoła, jako treść życia religijnego jednostek i wspólnot społecznych - są to trzy stadia tej działalności, którą można podsumować dwoma słowami - Civitas Dei.

Nie wolno jednak zapominać o specyfice kulturowo-historycznego zadania, jakie przypadło w udziale wielkiemu ojcu Kościoła. Podstawowe historyczne zadanie chrześcijaństwa zachodniego tego czasu - zadanie o ogólnoświatowym znaczeniu - to uzasadnienie wbrew barbarzyńcom łacińskiej jedności. Jedność, która za wszelką cenę trzeba utrzymać i ocalić, nie jest jedynie jednością chrześcijańską i kościelną, ale i świecką, państwową. Dowodziliśmy już przecież, że zachodni Kościół został w tamtym czasie obciążony brzemieniem świeckiego społeczeństwa, które spoczywało na jego barkach. Wyłącznie dzięki Kościołowi utrzymywała się jedność państwowa, stosunki kościelne i świeckie połączyły się i splotły na tyle ściśle, że nie można jednoznacznie powiedzieć, gdzie kończy się Kościół, a gdzie zaczyna państwo.

75 Zob. tegoż, De peccatorum meritis et remissione, ks. I, rozdz. 31, \59.

76 Zob. tegoż, Pržeznaczenie świetych, rozdz. 14, \27, dz. cyt., s. 290-291. 
Chcąc nie chcąc zachodni apologeta broniący jedności wspólnoty chrześcijańskiej staje się w owym czasie apologetą łacińskiej jedności; jego nauczanie nie stanowi czystego i nieskażonego chrześcijaństwa: jego ideał jest niechybnie przepełniony motywami świeckimi, państwowymi. Świadomie czy też nieświadomie uczestniczy w budowie nowego chrześcijańskiego Rzymu, w którym daje się odczuć także stary Rzym pogański. Ideał wiecznego państwa Bożego jest wprost antytezą pogańskiego wiecznego miasta, jest idealnym anty-Rzymem.

Nie można nazwać Augustyna apologeta czystego chrześcijaństwa, ale apologeta jego zachodniej jednostronnej formy. Laciński ideał, przeciw któremu w tym czasie występuje i któremu zagraża świat barbarzyński, stanowi przede wszystkim ideał powszechnego prawa, powszechnego porządku prawnego. Aby pokonać barbarzyńców, należy przeciwstawić im nieprzekraczalne ponadludzkie prawo. Pojęcie powszechnego boskiego prawa, urzeczywistniającego się we wszystkim i wszystko sobie podporządkowującego, jest rzeczywiście centralnym pojęciem światopoglądu Augustyna, jak to jeszcze dalej wykażemy.

W sporze z manichejczykami, dzielącymi wszechświat na dwa królestwa, Augustyn broni zasady boskiego jedynowładztwa w porządku kosmicznym. Co jednak staje się tu centralnym i najwyższym wyrazem boskiej władzy, której wszystko jest podporządkowane? Prawo, którym Bóg od wieków wszystko porządkuje, jeden jedyny ład (ordo), przy pomocy którego wszystko zostaje unormowane, a nie miłość, która przyciaga wszystko do Siebie i która jedna wszystko ze Soba. Jeden jedyny ład to najwyższy przejaw boskiej władzy, początek i koniec wszystkiego, co istnieje. Z punktu widzenia Augustyńskiej teodycei cierpienie lub potępienie to nic nieznaczący fakt, ponieważ istota stworzona nie jest w stanie naruszyć ładu we wszechświecie. Triumf prawa wyraża się tak w zwycięstwie dobra, jak w ukaraniu zła; co więcej, zło to konieczna antyteza dobra, bowiem ono - tak jak cień na obrazie - pozwala jaśniej i wyraźniej ukazać się światłu. Fundamentalne chrześcijańskie twierdzenie o boskiej miłości, której drogie jest każde stworzenie jako takie, nie stanowi centralnej idei w nauczaniu Augustyna ani w polemice z manichejczykami, ani w jego późniejszych dziełach. Najwyższą zasadą określającą stosunek Boga do stworzenia nie jest dla niego miłość, lecz ład, prawo chroniące tych, którzy go przestrzegaja, a karzące tych, którzy mu się sprzeciwiaja. Z takiego punktu widzenia miłość nie jest powszechnym i bezwyjątkowym stosunkiem Boga do stworzenia, lecz jedynie jednym z przejawów wiecznego boskiego porządku. Charakterystyczny wydaje się stosunek Augustyna do dogmatu 
o wcieleniu. Traktuje on tę centralną zasadę chrześcijaństwa jedynie jako jeden z momentów światowego ładu. Przyjęcie przez Boga ludzkiej natury nie stanowi absolutnego celu, ale jedynie środek do przywrócenia ładu naruszonego przez grzech człowieka. Celem wcielenia nie jest ono samo, lecz po części zadośćuczynienie boskiej sprawiedliwości, która domaga się bezkrwawej ofiary ${ }^{77}$, a po części też wychowanie rodzaju ludzkiego, zdolnego przyjąc boski ład tylko w dostępnej ludzkim zmysłom, człowiekowi podobnej formie. Tym sposobem Augustyn sprowadza centralną prawdę chrześcijaństwa do poziomu pojedynczego incydentu, sprowokowanego przez grzech człowieka. Wysuwa przeciw manichejczykom łacińską teokrację jako wszechmocne wieczne prawo, względem którego człowieczeństwo Bóstwa ma tylko podrzędne znaczenie środka, narzędzia.

Typowo łaciński charakter ma również apologia jedności Kościoła, sformułowana w sporze Augustyna z donatystami. Istota tego sporu jest to, że apologeta kościelnej jedności staje się w sposób nieunikniony także apologeta jedności wspólnoty państwowej, świeckiej. Bowiem jeśli donatyzm stanowi powstanie afrykańskiego nacjonalizmu przeciw uniwersalistycznej idei Rzymu wyrażającej się tak w Kościele, jak w państwie, to Kościół powszechny staje się $\mathrm{w}$ tym sporze przedstawicielem idei powszechnego porządku prawnego. W polemice z donatystami Augustyn postrzegał Kościól jako organizm prawny, dysponujący w walce $z$ heretykami siła świeckiego miecza, a więc jako wymuszona przez przemoc jedną wspólnotę. Sam Augustyn początkowo sprzeciwiał się przemocy. „Mój początkowy pogląd - pisze biskup Hippony - sprowadzał się do tego, że nikt nie powinien być zmuszany do jedności z Chrystusem; że trzeba działać słowem, walczyć przy pomocy rozumowania, zwyciężać rozumem, żeby z tych, których znaliśmy jako jawnych heretyków, nie zrobić pozornych katolików"78. Tak sądził Augustyn jeszcze w 404 roku na synodzie w Kartaginie. Jako myśliciel głęboko religijny pragnął intymnego, wewnętrznego zjednoczenia z Bogiem, a nie zewnętrznej wymuszonej jedności. Lecz widział również ówczesne rzymskie - a tym bardziej afrykańskie - społeczeństwo, na które trudno było wpłynąć przekonywaniem lub nauczaniem; można było je zwyciężyć jedynie strachem i przemoca. Obserwując własnymi oczyma bezdenną otchłań zepsutej natury ludzkiej, dostrzega, że zbiorowość ludzką w jej obecnym grzesznym stanie można skłonić do dobra jedynie siłą. Zgodnie z tym jedność w Chrystusie stanowi niechybnie dla ogromnej

\footnotetext{
${ }^{77}$ W tym względzie Augustyn przychyla się do popularnej w tamtym czasie na Zachodzie łacińskiej jurydycznej teorii zbawienia.

${ }^{78}$ Augustyn z Hippony, Ad Vincentem, Epist. XCIII, rozdz. 5, \ 17.
} 
większości coś zewnętrznego i wymuszonego. Poza tym, aby ocalić społeczeństwo w rozkładzie, trzeba koniecznie zmusić je do schronienia się za kościelnymi murami. Za wszelką cenę potrzebna jest jedność i jeśli nie można osiagnąć jej przy pomocy duchowego oręża, to pozostaje uciec się do świeckiego miecza.

$\mathrm{Na}$ oczach Augustyna za nawrócenie heretyków rzeczywiście wzięło się państwo i zakończyło się to sukcesem. Za postanowieniami synodu w Kartaginie w 404 roku (i właściwie na prośbę samego synodu, na którym przegrało liberalne stanowisko Augustyna) podążyły surowe edykty imperatora Honoriusza ${ }^{79}$, które rozpoczęły prawdziwe prześladowania donatystów. I tak, za sprawą środków przymusu donatyści zaczęli masowo przechodzić do panującego Kościoła. „Obserwujemy, że już nie te lub inne grupy osób, ale całe miasta będące wcześniej w rękach donatystów stały się teraz katolickimi - pisze Augustyn w 408 roku - nienawidzą diabelskiego podziału i płomiennie miłują jedność wspólnoty”, a ,stały się katolickie na skutek rozporządzeń imperatora"80. Pod wpływem tych wydarzeń Augustyn porzuca swoje poprzednie stanowisko, w 408 roku obalając poglądy, które sam głosił jeszcze w 404 roku. Bezpodstawności porzuconego przez niego poglądu dowodzą już nie spory przeciwników, ale fakty, przykłady z życia. Hippona - miasto, w którym Augustyn był biskupem i które do czasu imperatorskich postanowień było prawie całkowicie zamieszkane przez donatystów - na skutek edyktów w całości nawróciła się na katolicyzm $^{81}$.

Augustyn był w większym stopniu apologetą pewnego obiektywnego historycznego systemu niż głosicielem swych własnych religijnych zapatrywań. Jedność powszechnej Boskiej struktury stanowiła jego ideał i oto na jego oczach urzeczywistniła się ona na drodze przymusu i przemocy. W świeckich środkach przymusu wobec heretyków widzi on teraz fakt niezbędny, opatrznościowy. Działanie Bóstwa na naszą zepsutą naturę powinno być z konieczności połączone z przymusem. „Któż może kochać nas bardziej niż Bóg - zakrzyknie Augustyn - a jednocześnie nie zaprzestaje on swych dobroczynnych nauk, ale i przestrasza nas ku naszemu pożytkowi" ${ }^{82}$. Sam Bóg wykorzystuje przymus, co widać na przykładzie apostoła Pawła, „,który został zmuszony do poznania i zdobycia prawdy za sprawa wielkiego przymusu Chrystusa”. Bóg też zaleca przemoc, co widać w przy-

\footnotetext{
${ }^{79}$ Honoriusz był imperatorem Cesarstwa Zachodniego w latach 395-423. Wspomniany edykt został wydany w $405 \mathrm{r}$. [przyp. tłum.].

${ }^{80}$ Augustyn z Hippony, Ad Vincentem, XCIII, rozdz. 5, \16.

${ }^{81}$ Zob. tamże, rozdz. 5, \17.

${ }^{82}$ Tamże, rozdz. $2, \S 4$.
} 
powieści o gospodarzu, który posyłając swego sługę, aby zapraszał gości na wieczerzę, mówi do niego: „zmuszaj do wejścia” (Łk 14,23: w łacińskim tekście: coge intrare $)^{83}$. Jeśli weźmie się pod uwagę charakterystyczne dla tej epoki pomieszanie porządku kościelnego z państwowym, nie dziwi to, że Augustyn miesza porządek łaski z porządkiem prawnym, a świecki przymus bierze za konieczny sposób działania łaski. W jego teorii z tego, że Bóg przestrasza i karze, wynika bezpośrednio, że i państwo powinno straszyć i karać heretyków, co znaczy - spełniać obowiązki pasterskie. Lecz z drugiej strony dla Augustyna także władza duchowa dysponuje siłą i moca władzy państwowej, bowiem i „pasterz powinien niekiedy biczem zaganiać do stada zabłąkane owce". Herezja podpada dla niego pod tę samą kategorię, co powszechne przestępstwa karalne: jeśli państwo wymierza karę złodziejom i fałszerzom pieniędzy, to tym bardziej powinno karać heretyków!

W ten sposób $\mathrm{w}$ polemice $\mathrm{z}$ donatystami łaciński pierwiastek prawny zatriumfował nad indywidualnym usposobieniem religijnym Augustyna i stał się on - chcąc nie chcąc - apologetą Kościoła-państwa przeciwko antykościelnemu i antypaństwowemu ruchowi donatystów.

Ten łaciński pierwiastek z taką samą siłą dochodzi do głosu w antypelagiańskiej działalności pisarskiej wielkiego ojca Kościoła.

Natura ludzka została zgnębiona przez siłę zła, a wolność człowieka stała się jedynie negatywną, złą zasada - to właśnie jest centralne przekonanie Augustyna, stanowiące owoc badań i doświadczeń całego życia. Nic dziwnego, że dobro jawi mu się jedynie jako absolutnie ponadludzka zasada, a łaskę traktuje jak fatum, dokonujące zbawienia człowieka za cenę zniweczenia jego wolności. Sens i istota fundamentalnego pryncypium chrześcijaństwa są zaś takie, że zbawienie nie może być dziełem ani samego tylko Boga, ani samego tylko człowieka. Chrześcijańska idea bogoczłowieczeństwa wymaga prócz działania łaski z góry, także i współdziałania ludzkiej wolności w dziele zbawienia. Lecz ludzkość taka, jaką obserwował ją Augustyn, nie była ludzkością zdrową i normalną, nie ma więc nic dziwnego w tym, że zbawienie wydawało mu się jednostronnym działaniem łaski, w którym pierwiastek ludzki skazany był na pasywną jedynie rolę.

W rozpadającym się społeczeństwie wolność była pryncypium niszczącym, odśrodkowym, a pelagianizm ukazał jego prawdziwy stosunek do ustroju społecznego tamtego czasu. Pryncypium wolności w doktrynie pelagiańskiej wyrażało się tak samo jak w całości ówczesnej rzeczywistości historycznej - w zaprzeczeniu organicznej społecznej jedności i w buncie przeciwko mistycznemu organizującemu działaniu łaski. Przez wzgląd na $\overline{{ }_{83} \text { Tamże, rozdz. 2, } \$ 5 .}$ 
zbawienie społeczeństwa ta niszcząca zdolność musi zostać przemocą stłumiona i okiełznana: dla mas kolektywna jedność organizmu kościelnego mogła być jedynie czymś wymuszonym za cenę przemocy. Oto wyjaśnienie osobliwości Augustyńskiej doktryny łaski.

Łaska Boża stanowiła dla niego wszechpotężną nieodpartą siłę. To ona, rękami barbarzyńców niszczących świecką potęgę Rzymu, tworzy jego duchowa siłę. To łaska za sprawą świeckiego miecza prowadzi ludzi ku jedności w Chrystusie. Ona też triumfuje poprzez upadek i upokorzenie ludzkiej siły, zsyła na ludzi klęski, aby ich pouczyć, działa na nich przez wstrząsy i uderzenia, potrząsa fundamentami wszechświata i dokonuje cudu zbawienia człowieka, burząc, gwałcąc i niszcząc. Dla ówczesnego społeczeństwa - chrześcijańskiego tylko z nazwy, a pogańskiego w swej istocie - łaska jest prawem narzucanym zewnętrzną przemoca, surowym i bezwzględnym, bowiem staje się potępieniem i unicestwieniem tego społeczeństwa; względem niego jest jak fatum.

Tak rzeczywiście powinni postrzegać działanie łaski chrześcijanie tamtego czasu, lecz Augustyn uznał uwarunkowany czasowo przejaw łaski za powszechne prawo jej działania. „A więc przeznaczenie Boże, którego przedmiotem jest dobro - mówi biskup Hippony - to przygotowanie łaski, jak uprzednio powiedziałem. Łaska zaś jest skutkiem przeznaczenia"84. Przeznaczenie (czy też predestynacja) - owo wieczne prawo, wedle którego Bóg wszystko unormował - jest, z punktu widzenia Augustyna, uniwersalna relacją Boga do stworzenia, a łaska stanowi jedno z Bożych działań. Predestynacja to prawo wszechświata, realizujące się w całej strukturze kosmosu, tak w zbawieniu bogobojnych, jak i w potępieniu złych - prawo to rozciaga się na wszystkich. Laska ocala tylko niektórych, wybranych, których przeznaczono do zbawienia. Sfera jej działania jest ograniczona: ma się tak do predestynacji, jak szczególne do ogólnego. Tak zbawienie, jak i potępienie ludzi zostało odwiecznie predestynowane. Z takiego punktu widzenia nie można oczywiście mówić o jakimkolwiek wolnym współuczestnictwie człowieka w dziele zbawienia. Każde poruszenie ludzkiej woli ku dobru jest jedynie automatycznym powtórzeniem przedwiecznego aktu Boga, łaska zbawiająca wedle odwiecznego przeznaczenia stanowi zupełne zaprzeczenie wolności.

Na tym polega ogromna niedoskonałość nauczania Augustyna. Jeśli przyjmiemy warunkowy historyczny punkt widzenia, to będziemy zmuszeni przyznać, że w odniesieniu do swojego historycznego otoczenia i epoki

${ }^{84}$ Tenże, Przeznaczenie świetych, rozdz. 10, \19, dz. cyt., s. 283; Praedestinatio Dei, quae in bono est, gratiae est, ut dixi, praeparatio; gratia vero est prius praedestinationis effectus. 
ma rację. Wielki powszechny kryzys historyczny, który rozwijał się na jego oczach, rzeczywiście stanowił akt wielkiej przemocy Chrystusowej wobec grzesznej ludzkości, i o tyle też jest triumfem Augustyńskich zasad i porażka pelagianizmu. Aby jednak dokonać wielostronnej oceny tego nauczania, które przede wszystkim chce być chrześcijańskim, trzeba naświetlić jego stosunek do chrześcijaństwa jako całości. Jeśli spojrzymy na nie z uniwersalnego punktu widzenia, to łatwo przekonamy się o tym, że zawiera w sobie pewne odstępstwo od fundamentalnych zasad chrześcijaństwa. Już wcześniej, kiedy charakteryzowaliśmy antymanichejskie utwory wielkiego ojca Kościoła, dostrzegliśmy, że centralna idea chrześcijaństwa - wcielenie - nie stanowi centralnej zasady jego nauczania. To samo należy powiedzieć o jego działalności antypelagiańskiej. Również tutaj podstawowe pojęcie stanowi wieczny ład, prawo, działające na zasadzie predestynacji, a nie boska i ludzka zarazem osoba Chrystusa. Wedle nauki Augustyna Chrystus jest najwyższym przejawem łaski: w Nim „w Głowie naszej [to jest - Głowie Kościoła - J.T.] ukaże się nam źródło łaski”, stąd rozlewa się ona „po wszystkich członkach ciała”. Chrystus jest człowiekiem, którego naturę Słowo Boże przyjęło i z którym się zjednoczyło bez jakichkolwiek poprzedzających to zasług (nullis suis praecedentibus meritis). Chrystus, będąc najwspanialszym znakiem działania pryncypium łaski, jest z tego powodu także najwyższym przejawem predestynacji. „Nikt nam nie daje znakomitszego przykładu przeznaczenia niż sam Jezus" (Nullum autem est illustrius praedestinationis exemplum quam ipse Iesus). „Niech każdy wierny, chcący dobrze zrozumieć przeznaczenie, patrzy na Jezusa, a w Nim odnajdzie siebie”. Bóg - bez żadnych uprzednich zasług - uczynił sprawiedliwym człowieka z rodu Dawida, którego naturę przejęło słowo Boże, tak samo postąi ze świętymi, których na to przeznaczył. Bóg współdziała w ludziach, tak jak współdziałał w Chrystusie, aby czynili Jego świętą wolę. Stwórca wszechświata „przeznaczył Chrystusa i nas, Bóg z góry wiedział, że nie przyszłe zasługi Chrystusa czy nasze, ale Jego własne przyszłe dzieła czynią Chrystusa głową naszą, a nas Jego członkami" 85 .

Tym sposobem Augustyn sprowadza ludzką wolę Chrystusa, jak i ludzką wolę w ogóle, do poziomu pasywnego środowiska działania łaski, automatycznego narzędzia predestynacji. Ponieważ zaś sama łaska nie jest powszechnym i uniwersalnym sposobem działania Boga, lecz jedynie jednym ze skutków predestynacji, to i człowieczeństwo Chrystusa, będące przede

${ }^{85}$ Zob. Augustyna z Hippony, Præęnaczenie śmietych, rozdz. 15, [dz. cyt., s. 293]; Nagana a laska, rozdz. 11, [w: Łaska, wiara, przeznaczenie, dz. cyt., s. 189-192]; Dar wytrwania, rozdz. 24, [w: Laska, wiara, przeznaczenie, dz. cyt., s. 383-384], skąd zapożyczyłem wszystkie przytoczone powyżej cytaty. 
wszystkim wyrazem łaski, staje się tylko jednym z wielu przejawów uniwersalnego prawa predestynacji.

Taka chrystologia Augustyna stanowi najlepszy wskaźnik stosunku jego teokratycznego ideału do idei chrześcijaństwa. Ideał chrześcijański wymaga doskonałego pogodzenia ludzkiej wolności z łaską Bożą w Chrystusie - organicznej jedności i wzajemnego oddziaływania wolnego Bóstwa i wolnego człowieczeństwa. Poza tym nauczanie Augustyna zasadniczo zaprzecza ludzkiej wolności w Chrystusie. Oczywiście z punktu widzenia uniwersalnej idei chrześcijaństwa nasz grzeszny stan także jawi się jako stan względnego zniewolenia, ale nauczanie Augustyna czyni z tego względnego czasowego stanu wieczne i absolutne pryncypium, na tym też właśnie polega odstępstwo od chrześcijaństwa, którego Augustyn dopuszcza się w swoim nauczaniu.

Najważniejszym pojęciem w nauczaniu ojca Kościoła jest ład we wszechświecie, powszechne panowanie Boskiego prawa stanowi jego społeczny ideał. Ideał powszechnego Boskiego prawa i prawdy, będącej uniwersalną normą stosunków społecznych, jest niezbędnym aspektem chrześcijaństwa, a błąd Augustyna polega jedynie na tym, że uznał część za całość, jeden z wymiarów chrześcijaństwa za chrześcijaństwo jako takie i uczynił jeden z momentów składowych najwyższa zasada. Ten błąd nie jest jednak osobista pomyłką wielkiego ojca Kościoła, lecz osobliwością owej jednostronnej formy chrześcijaństwa, którą biskup Hippony reprezentuje.

Jak już powiedziano, Augustyn to apologeta obecności łacińskiej idei w chrześcijaństwie, a ponieważ uznaje on ten łaciński pierwiastek za coś najwyższego i bezwarunkowego, to - chcąc nie chcąc - przechodzi na stronę rzymskiego pogaństwa, ustępując przed siłą wielowiekowego dziedzictwa łacińskiego Zachodu.

W tym punkcie spotyka się ze swoim przeciwnikiem Pelagiuszem, gdyż pomimo licznych wzajemnych rozbieżności i różnic stoją oni na wspólnym historycznym gruncie. Jeśli weźmiemy w nawias głęboką opozycję myśli, orientacji i charakteru obu myślicieli, jeśli pominiemy na chwilę ogromną przewagę wielkiego ojca Kościoła nad potępionym przez Kościół heretykiem, to w nich obu dostrzeżemy łatwo wspólne rodowe cechy łacińskiej odmiany chrześcijaństwa.

Ostatecznie obaj przecież głoszą zbawienie według prawa, obaj czynia z prawa absolutne pryncypium. U Pelagiusza jednak najwyższym pryncypium jest prawo będące zewnętrzną, empiryczną norma - od jej przestrzegania zależy zbawienie, u Augustyna zaś najwyższą zasadę stanowi 
przedwieczne prawo Boże, rozumiane jako predestynacja. Fundamentalna różnica między jednym a drugim polega na tym, że wykonawczynią prawa jest dla Pelagiusza wolna wola człowieka, nagradzana za swoje zasługi, a dla Augustyna jest nią łaska, działająca zgodnie z Boska predestynacją. Pierwszy przypisuje zbawienie jednostronnemu działaniu człowieka, drugi - Bóstwa. U obu zaś jurydyczny pierwiastek wyraża się poprzez umniejszenie znaczenia boskiej i ludzkiej zarazem osoby Chrystusa. Bowiem jeśli dla Pelagiusza życie i cierpienia Chrystusa stanowią tylko Jego własną zasługe wobec prawa, pozbawiona uniwersalnego kosmicznego znaczenia, to dla Augustyna - jak widzieliśmy - człowieczeństwo Chrystusa to tylko jeden z wielu przejawów odwiecznego prawa, a społeczne oddziaływanie łaski ma ograniczony zasięg.

Pelagianizm zawiera w sobie jeden $\mathrm{z}$ aspektów chrześcijańskiego ideału teokratycznego - ten, którego brakuje u Augustyna: ideał ten wymaga takiej ludzkiej woli, która byłaby w stanie w sposób wolny współdziałać z łaska. Z perspektywy tego ideału Pelagiusz ma rację, wzywając ludzką wolność do działania, ale jego nauczanie ma charakter antychrześcijański i antyteokratyczny, ponieważ umacnia wolność w sposób jednostronny, ponieważ izoluje ludzką wolę od społecznego organizującego działania łaski. Chrześcijańska teokracja nie chce być dziełem tylko ludzkich rąk i jeśli tak się spojrzy na ten problem, to Pelagiusz się myli.

Z drugiej jednak strony Augustyn, reprezentując pogląd przeciwstawny, ale równie jednostronny - tak samo jak jego pelagiańscy oponenci jednocześnie ma rację i jej nie ma. Chrześcijańska teokracja nie chce być dziełem samego Bóstwa i potrzebuje wolnej ludzkości jako fundamentu dla działania łaski.

Będąc doktryną jednostronna, augustynizm nie mógł nigdy przezwyciężyć przeciwnej względem niego jednostronności - pelagianizmu, który przeciwstawiał mu się nie bez pewnej, choć mniejszej, historycznej racji.

Pomijając jednak już względną słuszność augustynizmu, odpowiadającego bardziej ideowym żądaniom i wydarzeniom swojej epoki, posiada on jeszcze jedną olbrzymią zaletę. Pelagianizm, będąc światopoglądem indywidualistycznym i antykościelnym, nie trzyma się w swym rozwoju kościelnej tradycji, którą wkrótce ostatecznie porzuci. Jednostka pozostawiona jest tu na pastwę swojego indywidualnego sądu i samowoli - oto dlaczego pelagianizm mógł tak szybko odejść od chrześcijaństwa, ukazując swą pogańską specyfikę. Augustyn znajduje się w innej sytuacji. Pełniąc funkcję apologety społecznego życia Kościoła i kościelnej struktury, jest w swym głoszeniu bardziej powściagliwy. Poza tym - choć w tamtym cza- 
sie osobliwości obu części chrześcijaństwa, wschodniej, greckiej i zachodniej, łacińskiej, wyraźnie się już ujawniły, to nie rozpoczął się jeszcze ich bratobójczy spór. Osobliwości te były powściągane i łagodzone za pomocą wspólnych powszechnych zasad chrześcijańskich, na gruncie których utwierdzało się i utrzymywało ogólnoświatowe chrześcijańskie zjednoczenie. Dobroczynne i zbawcze działanie tych zasad znajdowało swój wyraz w codziennym życiu Kościoła i w utworach myślicieli chrześcijańskich, znalazło swój wyraz również w nauczaniu Augustyna. Laciński pierwiastek zawarty w tym nauczaniu został złagodzony i powściąnięty nie tylko przy pomocy bogactwa chrześcijańskich idei, które mieści w sobie Augustyńska nauka, ale i poprzez głęboko chrześcijańskie indywidualne usposobienie ojca Kościoła.

Głęboko religijny geniusz Augustyna oburzał się i buntował przeciwko przemocy: gorąco pragnął wolności, a zmuszony był toczyć boje za system zbudowany na fundamencie stłumionej wolności i przemocy. System ten nie był jego osobistym wymysłem, ale narzuciła mu go historia. Zmagał się z nim, a to zmaganie znalazło swój wyraz w niezliczonych wahaniach, niekonsekwencjach i subiektywnych sprzecznościach. Ostatecznie obiektywna historyczna siła złamała i ujarzmiła Augustyna, zmusiła go, aby zmieścił się w ramach łacińskiego systemu i wbrew woli uczyniła go jego ojcem i założycielem.

Biskup Hippony nie był oczywiście tylko apologetą rzymskości: prócz tego uwiecznił on swoje chrześcijańskie usposobienie w cudownym, nieśmiertelnym wizerunku. Specyfiką tego religijnego usposobienia jest to, że nie da się zamknąć w ramach jakiegokolwiek systemu. Życie religijne jednostki stanowi dla Augustyna przede wszystkim intymny i bezpośredni stosunek człowieka do Boga, który można scharakteryzować słowami „żyć w Bogu”, ,przylgnać do Boga”. W Wyznaniach Augustyn przedstawił proces religijnego poszukiwania, które znajduje ukojenie jedynie w doskonałej pewności posiadania Boga. Podstawowe aspekty jego indywidualnego usposobienia - głęboko religijnego i głęboko chrześcijańskiego - to żarliwa miłość do Boga przy jednoczesnej głębokiej świadomości ludzkiej grzeszności, zaufanie do Boga i nadzieja na wybaczenie ${ }^{86}$.

Lecz owe chrześcijańskie pierwiastki w usposobieniu Augustyna nie w pełni harmonizuja z jego systemem, a częściowo pozostają z nim w bezpośredniej sprzeczności i niezgodzie. W istocie są one ciosem w samo serce

${ }^{86}$ Por. znakomitą charakterystykę usposobienia religijnego Augustyna u A. Harnacka: Dogmengeschichte, t. III, dz. cyt., s. 54-58 i tegoż, Augustin's Confessionen. Ein Vortrag, Giesen 1888 [wykład Harnacka z 1887 roku]. 
systemu. Bowiem jeśli najwyższym pryncypium w relacji Boga do stworzenia nie jest miłość, ale beznamiętne zimne prawo, obdarzające każdego tym, co mu należne, jeśli zbawcze działanie łaski jest ograniczone do małej liczby predestynowanych wybranych, jeśli - wreszcie - Syn Boży nie jest odkupieniem wszystkich, lecz tylko niektórych, to nikt nie może być pewny swojego zbawienia. Nie może być więc tutaj mowy o zaufaniu do Boga, a stosunek człowieka do Boga przekształca się w wieczny strach, którego nie można zrównoważyć nadzieją. Z punktu widzenia „ładu” potępienie czy zbawienie człowieka jest nieistotnym faktem; poszczególne indywiduum nie stanowi celu, pozbawione jest bezwarunkowej ceny i znaczenia.

Z tego też powodu system Augustyna nie dostarcza dostatecznych obiektywnych przesłanek dla religijnej nadziei i nie obdarza ukojeniem w Bogu, którego poszukuje Augustyńskie usposobienie. Dlatego też Augustyn jest dużo sympatyczniejszy w swoich $W_{y} \not$ naniach, niż w swoim nauczaniu, o wiele bardziej pociagające jest to, czego szukał, niż to, co znalazł.

Augustyn odniósł zwycięstwo nad Pelagiuszem w sporze o idealne podstawy nowego społeczeństwa, lecz zwycięstwo to nie mogło być pełne: pelagianizm w swej czystej postaci został potępiony na Soborze efeskim ${ }^{87}$ i bardzo szybko całkowicie znikł, ale nie przestał istnieć pod postacią semipelagianizmu. I w tej postaci był niejednokrotnie potępiany przez Kościól rzymski, lecz i tak nieustannie odradzał się na Zachodzie pod postacią kolejnych ortodoksyjnie katolickich doktryn. Augustyn przeciwnie, został kanonizowany i uznany za autorytatywnego nauczyciela Kościoła, lecz wiele z jego nauk było niejednokrotnie potępianych, choć nie bezpośrednio pod jego imieniem (tym sposobem razem z jansenizmem zostało potępionych wiele twierdzeń wprost Augustyńskich). Augustyn nie mógł zniszczyć swojego przeciwnika dlatego, że również on cierpiał na wspólną dla nich chorobę, ponieważ sam w pełni nie przezwyciężył w sobie łacińskiego pogaństwa.

Jako że z prawa czyni się najwyższe i absolutne pryncypium, to rzeczywiście niemożliwe jest pogodzenie łaski z wolnością. Jeśli łaska może zatriumfować jedynie na drodze zniszczenia ludzkiej wolności, to dla ludzkiej woli stanowi ona z konieczności jedynie obce i zewnętrzne prawo. Stąd też $\mathrm{i}$ wolność zmienia się w bezwzględnie wrogie wobec łaski pryncypium. Jeśli prawo stanowi konieczny i powszechny sposób działania łaski, to łaska i wolność stanowią zewnętrzne, obce i wrogie sobie sfery. Dla jurydycznego chrześcijaństwa spór o łaskę stanowi jedynie nierozwiązywalną

${ }^{87}$ „Sobór powszechny w Efezie (431) powtórzył potępienie doktryny pelagiańskiej, potwierdzając Epistolam tractoriam papieża Zozyma" - B. Kumor, t. I, dz. cyt., s. 186 [przyp. tłum.]. 
sprzeczność: musi ono wiecznie wahać się między przeciwstawnymi i jednakowo niezadowalającymi rozwiązaniami Augustyna i Pelagiusza. Dla chrześcijaństwa łacińskiego ten spór ma decydujące znaczenie, lecz tylko dlatego, że ze swojej osobliwości czyni ono najwyższe pryncypium, uznając wyłącznie siebie za całe chrześcijaństwo. To pryncypium nie stanowi jednak dla niego niebezpieczeństwa, ponieważ chrześcijaństwo łacińskie stoi na gruncie powszechnego chrześcijańskiego ideału. Z perspektywy fundamentalnego chrześcijańskiego pryncypium - bogoczłowieczeństwa - stosunek łaski i wolności to bowiem wieczna wrogość: walka między nimi jest przejawem niedoskonałej ziemskiej rzeczywistości. Ponieważ grzeszna ludzkość odrzuca łaskę, ta rzeczywiście staje się dla niego zewnętrznym prawem. W rzeczywistości wiecznej łaska godzi się z doskonałą ludzką wolnością w doskonałym bogoczłowieczeństwie.

Nauczanie Augustyna zostało osłabione przez zawarty w nim łaciński pierwiastek pogański. Pogaństwo było w istocie jego głównym i najsilniejszym wrogiem. Augustyn walczył z nim i odniósł zwycięstwo, lecz nie mogło być ono pełne: pogaństwo wsiąkło w światopogląd wielkiego ojca Kościoła, nie przestając istnieć w nim pod postacią nauki chrześcijańskiej. Utwierdzimy się w tym przekonaniu, analizując dzieło De Civitate Dei, w którym Augustyn rozlicza się z pogaństwem. Postawił on sobie w tym utworze zadanie zaprezentowania wszechstronnej apologii chrześcijańskiej idei państwa Bożego przeciwko rzymskim poganom, przypisującym chrześcijaństwu upadek Rzymu. Pogańskiej idei Rzymu przeciwstawia się w nim bezpośrednio państwo Boże. Mamy więc w tym dziele do czynienia z najważniejszym stadium apologetycznej działalności Augustyna, mieszczącym w sobie wszystkie wcześniejsze stadia i przewyższającym je wszystkie swoim znaczeniem. O nim też będziemy mówić w kolejnym artykule.

Pržetożyt Michat Rogalski 